Işın, A., Ünlüönen, K. / Journal of Yasar University, 2020, 15/59, 461-479

\title{
Yerel Yiyecek Tüketiminde Gıda Korkusu ve Kültürün Moderatör Etkisi: Yabancı Turistler Üzerine Bir Araştırma ${ }^{1}$
}

\section{Moderator Effect of Food Neophobia and Culture on Local Food Consumption: A Research on Foreign Tourists}

\author{
Alper IŞIN, Ankara Hacı Bayram Veli Üniversitesi, Türkiye, alper.isin@hbv.edu.tr \\ Orcid No: 0000-0003-2232-0606 \\ Kurban ÜNLÜÖNEN, Ankara Hacı Bayram Veli Üniversitesi, Türkiye, kurban.unluonen@hbv.edu.tr
} Orcid No: 0000-0002-4191-9019

\begin{abstract}
Öz: Turistler tatil için gittikleri bölgelerde yerel yiyecek tüketmeyi tercih etmektedir. Bu nedenle turistlerin bölge ile ilgili hatıralarında olumlu/olumsuz bir imajın oluşumunda yerel yiyecekler oldukça önemlidir. Bu çalışmanın amacı, Türkiye'yi ziyaret eden yabancı turistlerin yerel yiyecekleri tüketme niyetlerinin tespit edilmesidir. Bu amaçla birlikte yabancı turistlerin yiyecek tüketimi ile ilgili kişilik özelliklerinin (glda korkusu) ve ait olduklar kültürlerin de yiyecek tüketme niyetini ne yönde etkilediği belirlenmeye çalışılmıştır. Araştırmanın verileri Türkiye'nin üç farklı destinasyonunu (Istanbul, Antalya ve Nevşehir) ziyaret eden ve yerel yiyecekleri deneyimleyen 47 farkl milliyetten olan yabancı turistlerden (n:644) toplanmiştır. Bulgular incelendiğinde, teori ile örtüșen bir șekilde turistlerin tutum, öznel norm ve algılanan davranışsal kontrollerinin, davranışsal niyetlerini etkilediği sonucuna ulaşılmıştır. Çalışmada moderatör değişken olarak belirlenen, gıda korkusu düzeyinin ve kültürün turistlerin davranışsal niyetleri üzerinde ise klsmen etkili olduğu tespit edilmiștir. Bununla birlikte farklı kültürel özelliklerinde yiyecek tüketimine yönelik davranışsal niyetler üzerindeki etkisi kusmidir.
\end{abstract}

Anahtar Sözcükler: Yerel Yiyecek Tüketimi, Gıda Korkusu, Kültür, Planlı Davranış Teorisi

JEL Sinıflandırmasi: D11, E21, L66, L83

Abstract: Tourists prefer to consume local food in regions where they go on vacation. For this reason, local food is very important for the formation of a positive / negative image in the memories of tourists about the region. The aim of this study is to determine the foreign tourists visiting Turkey behavioral intentions toward local food consumption. For this purpose, while determining the intention of tourists to consume local food, it was also tried to determine the personality traits (food neophobia) related to food consumption and how the cultures they belong to affect the intention to consume food. Research data gathered from 47 different nationalities foreign tourists who visited Turkey's three destinasitons (İstanbul, Antalya ve Nevşehir) and consume local food. When the findings are examined, it was determined that the attitude, subjective norm and perceived behavioral behaviors of the tourists affected behavioral intentions. It was determined that the level of food neophobia and the culture were partially effective on the behaviors of tourists. At the same time, different cultural characteristics have been found to be partly effective on behavioral intentions for food consumption as well.

Keywords: Local Food Consumption, Food Neophobia, Culture, Theory of Planned Behavior JEL Classisification: D11, E21, L66, L83

\section{Giriş}

Destinasyonu ziyaret eden turistler için o bölgede sunulan yiyecekler, öncelikli olarak beslenme ihtiyacını karşılarken, bir yandan da başlı başına bir seyahat sebebi ve kültürel bir çekim unsuru olabilmektedir.(Du Rand, Heath \& Alberts, 2003, 98). Bölgede sunulan yiyecekler, turistlerin yerele ait gelenekleri daha derinlemesine tanıyı o yöreye ait kültürü iyi anlaması ile kültürel alıșverișin bir mekanizması olarak da hizmet vermektedir (Marsh, Hau, Balla \& Grayson, 1998, 186). Ayrıca yerel yiyecek tüketimi, turistlere bir yenilik ve eğlence yaşatması sebebiyle seyahat boyunca oluşan deneyimin önemli bir parçası olarak da kabul edilmektedir (Tikkanen, 2007; Björk \& Kauppinen-Räisänen, 2016; Okumus \& Çetin, 2018). Yiyecek tüketiminin artan önemi neticesinde İtalya, Avustralya, Yeni Zelanda ve Singapur gibi bazı ülkelerin hükümetleri kendilerini rakiplerinden farklı kılmak için mutfaklarını ön plana çıkartmayı amaçlamaktadır (Chang, Kivela \& Mak, 2010; Hall \& Mitchell, 2005; Scarpato, 2002).

İnsanların yiyecek tüketimi davranışlarını etkileyen birçok unsur bulunmaktadır. Konu ile ilgili en eski çalışmalardan biri Pilgrim (1957) tarafindan yapılmıştır. Yazar, insanların yiyecek tüketimini etkileyen 3 temel faktör olduğunu belirtmektedir. Bunlar; yiyecek ile ilgili özellikler (örn. lezzet, tat, doku, aroma gibi duyusal özellikler, yiyeceklerin

\footnotetext{
${ }^{1}$ Bu makale, Alper IŞIN’ın “Planlı Davranış Teorisi Kapsamında Türkiye’ye Gelen Yabancı Turistlerin Yerel Yiyecekleri Tüketme Niyeti Üzerine Bir Araștırma" başlıklı doktora tezinden üretilmiștir.

Makale Gecmiși / Article History

Başvuru Tarihi / Date of Application : 26 Aralık / December 2019

Kabul Tarihi / Acceptance Date : : 24 Mart / March 2020

(C) 2020 Journal of Yaşar University. Published by Yaşar University. Journal of Yaşar University is an open access journal. There is no conflict of interest or ethical concern regarding this publication.
} 
bileşenleri, pişirme şekilleri, fiyat, kalite vb.), kişilik özellikleri (örn. kültürel karakterler, dini inançlar, demografik özellikler, motivasyonel faktörler, açlık, susuzluk gibi psikolojik faktörler vb.) ve çevresel özelliklerdir (örn. bölgenin gastronomik imajı, tv, internet gibi pazarlama araçları, hizmet kalitesi vb.). Mak ve diğerleri (2012) ise yapmış oldukları çalışmada, turistlerin yiyecek tüketimini etkileyen faktörlere yönelik bir model geliştirmişlerdir. Bu model daha önce Pilgrim'in geliştirmiş olduğu model ile uyum göstermektedir.

Bu modelde farklı olarak turizm sektörünün doğası ve turistik ürünlerin özellikleri gereği bazı eklemeler yapılmıştır. Ziyaret edilen destinasyondaki mutfağın geleneksel, otantik ya da yerel olması, turizm sektörünün bazı bölgelerde sezonluk özelliğinden dolayı yiyecek ve içeceklere ulaşımdaki değişimler ve yiyecek-içecek servisindeki hizmetin kalitesi yapılan eklemelere örnek olarak gösterilebilir (Işın, 2019, 197). Turistlerin yiyecek tüketimini etkileyen unsurlarla ilgili de literatürde pekçok çalışma bulunmaktadır (Wright, Nancarrow, \& Kwok, 2001; Kim, Eves, \& Scarles, 2009; Chang, Kivela \& Mak, 2010; Mak ve diğerleri, 2012; Zhang, Li, Yang, \& Zhang, 2018; Girgin, 2018; Semerci \& Akbaba, 2018; Lin, Julve, Xu \& Cui, 2018; Choe \& Kim, 2018; Promsivapallop \& Kannaovakun, 2019; Vuksanović, Tešanović, Kalenjuk \& Portić, 2019).

Wrigt ve diğerlerinin (2001) yapmış oldukları çalışmada turistlerin kültürel özelliklerinin yiyecek tadımında bir etkisinin olup olmadığı araştırılmış ve farklı kültürlerel özelliklere sahip insanların yiyeceklerin tadımında ve tercihlerinde etkili bir unsur olduğu sonucuna varılmıştır. Kim ve diğerleri (2009) ise yapmış oldukları çalışmada turistlerin seyahatleri boyunca yiyecek tüketimlerini etkileyen faktörleri motivasyonel, demografik ve psikolojik faktörler olmak üzere 3 boyutta incelemişler ve sonucunda 3 boyut altında yer alabilecek alt boyutları içeren birmodel ortaya çıkarılmıştır. Bir diğer çalışmada ise Vuksanović ve diğerleri (2019) Sırbistan'ı ziyaret eden turistlerin yiyecek tüketimlerinde yaş, cinsiyet ve eğitim durumlarının farklılık oluşturup oluşturmadığına yönelik bir araştırma yapmışlardır. Çalışma sonucunda farklı yaş gruplarında özellikle gençler ve 60 yaş üstündeki katılımcıların yiyecek tüketimleri arasında farklılıklar belirlenmiştir. Bunun yanı sıra yiyecek tüketimi konusunda kadın ve erkekler arasında da önemli bir farklılık belirlenmiş ve bu durumun cinsiyetler arasındaki psikolojik karakter farklarından kaynaklandığının tahmin edildiği belirtilmiştir.

Bu çalışmada, planlı davranış teorisi (PDT) kapsamında Türkiye'yi ziyaret eden yabancı turistlerin yerel yiyecek tüketimine yönelik davranışsal niyetlerinde gida korkusu ve kültür faktörlerinin düzenleyici bir etkisinin olup olmadığg araştırılmıştır. Çalışma 15 Mayıs - 15 Eylül 2018 tarihleri arasında İstanbul, Antalya ve Nevşehir destinasyonlarını ziyaret eden 47 farklı milliyete mensup 644 kişi ile gerçekleştirilmiştir.

\section{Kavramsal Çerçeve}

\subsection{Yerel Yiyecek Tüketimi}

Her ulusun medeniyet seviyesini yansıtan özelliklerden biri de tartışmasız onların yiyecek içecek kültürüdür. Yiyecek kültürü, özellikleri nedeniyle tüketicilerin kutlamaları üzerinde önemli bir rol oynamakta, sosyalleşmeyi, eğlenceyi, hassasiyeti içermekte ve yeni kültürler ve mutfakları deneme imkânı sağlamaktadır (Mitchell ve Hall, 2003: 67).

Turizmde yiyecek tüketimi turistler için, refahlarını sürdürmek, bir toplumun kültürünü deneyimlemek ve anlamak için oldukça önemlidir (Mintz ve Du Bois, 2002). Destinasyonun sahip olduğu yerel yiyecek ve içecekler bölgeye karşı bir sempati oluşturmakta. Kalitesiz yiyecekler ise, bölgenin tekrar ziyaret edilmesinde olumsuz etki oluşturmaktadır (Pendergast, 2006).

Yerel yiyecekler, bölgede yetiştirilen ürünler ile olmasa da, belirli bir bölgenin geleneksel yöntemlerini kullanarak hazırlanan yiyecekleri ifade eder (Chang ve diğerleri, 2010). Yerel yiyecekler turistler için önemli bir çekim unsuru olması nedeniyle, yerel gıda tüketiminin bölge için önemli bir ekonomik etkisi vardır (Mkono ve diğerleri, 2013; Kim ve diğerleri, 2016).

Turizm literatürü incelendiğinde, yerel yiyecekler ve turist davranışları ile ilgili birçok farklı konu araştırılmıştır. Örneğin, Kim, Suh ve Eves (2010) yapmış oldukları çalışmada yiyeceğe yönelik kişilik özelliklerinin (gıdaya yönelik korku ve gıdaya yönelik ilgi) memnuniyet ve sadakat üzerine etkisini araştırmışlardır. Güney Kore'de yerel bir yiyecek festivalinde yapmış oldukları bu araştırmada gıda korkusunun memnuniyet ve sadakat üzerinde olumsuz etkisinin olduğu belirlenmiştir. Bayrakçı (2014) çalışmasında yerel yemek tüketim motivasyonları ile tekrar ziyaret arasındaki ilişkiyi incelemiştir. Gaziantep'i ziyaret eden yerli turistler üzerine yaptığı araştırmada yemek motivasyonlarının destinasyonu tekrar ziyaret üzerinde olumlu etkisinin olduğu sonucuna ulaşılmıştır. Choe ve Kim (2018) ise çalışmalarında turistlerin yerel yiyecek tüketimleri ile destinasyon yiyecek imajı ve memnuniyet arasındaki ilişkiyi incelemişlerdir. Araştırma sonuçları turistlerin algıladıkları yerel gida tüketim değerinin, yerel yiyeceklere, destinasyon yiyecek imajına ve davranışsal niyetlere yönelik tutumlarını etkili bir şekilde açıkladığını göstermektedir.

Bu çalışmaların yanı sıra tüketicilerin yiyecek seçimindeki öncelikleri ve yiyecek tedariğine yönelik algıları ile yerel yiyeceklere yönelik algılamalar arasındaki ilişki (Weatherell, Tregear ve Allinson, 2003), yiyeceğe yönelik kişilik özelliklerinin memnuniyet ve sadakat üzerine etkisi (Kim, Suh ve Eves, 2010), yerel yemek tüketim motivasyonları ile tekrar ziyaret arasındaki ilişki (Kim ve Eves, 2012), yerel yiyeceklere yönelik tutum ile memnuniyet ve tekrar ziyaret (Di Pietro ve Campbell, 2014), yiyeceğe yönelik kişilik özelliklerin yiyecek tüketimi üzerine etkisi (Mak ve diğerleri, 2016) ve yemek alışkanlıkları ve turistlerin yiyecek tüketimleri (Lin, Julve, Xu ve Cui, 2018) gibi birçok farklı konu araştırılmıştır. 


\subsection{Yiyecek Tüketimini Etkileyen Unsurlar}

Turizm literatürü incelendiğinde turistlerin yiyecek tüketimini ve tercihlerini etkileyen faktörler üzerine yapılan araştırmaların bulunduğu görülmektedir (Randall ve Sanjur, 1981; Wright, Nancarrow ve Kwok, 2001; Kim, Eves ve Scarles, 2009; Chang, Kivela ve Mak, 2010; Mak ve diğerleri, 2012; Zhang, Li, Yang ve Zhang, 2018; Choe ve Kim, 2018; Promsivapallop ve Kannaovakun, 2019; Vuksanović ve diğerleri, 2019). Mak, Lumbers, Eves ve Chang (2012) yapmış oldukları çalışmada, turistlerin yiyecek tüketimini etkileyen faktörleri turist, yiyecek ve çevre olmak üzere 3 ana başlık altında değerlendirmişlerdir. Bu faktörler arasındaki en önemli başlık turistlerin kişisel özellikleri olarak belirtilmiştir. Turistlerin kültürel karakterleri ve yiyecek ile ilgili kişilik özellikleri (gıda korkusu, gıdaya yönelik ilgi vb.) seyahatleri esnasında yiyecek tüketimlerini etkileyen en önemli unsurlardan biri olarak dikkat çekmektedir.

Yiyecek ile ilgili kişilik özellikleri turistlerin yiyecek tüketimini etkileyen önemli psikolojik değişkenler olarak kabul edilmeye başlanmıştır. Yiyecek ile ilgili kişilik özellikleri, geniş bir yelpazede yiyecek ile ilgili davranışlar üzerinde yaygın bir etki oluşturan bireysel özelliklere atıfta bulunur (Pliner ve Salvy, 2006: 81).

Yapılan bazı araştırmalar yiyecek ile ilgili kişilik özellikleri ile tüketici davranışları arasında bir ilişki olduğu görüşünü savunmaktadır. Khan ve Hackler (1981) yaptığı çalışmada, bireysel özelliklerin ve çevresel faktörlerin birbiriyle bağlantılı olduğu ve kişilerin yiyecek tercihlerinde bireysel özelliklerin önemli bir rol oynadığını belirtmiştir. Ajzen (1987) ise çalışmasında, kişilik özelliklerinin insan davranışını öngörme ve açıklanmasında önemli bir etken olduğundan bahsetmiştir. Başka bir deyişle, bireyin kişisel özellikleri, bireyin sahip olduğu değerler aracılığıyla kişisel seçim kriterlerinin oluşturulmasında rol oynayabilir (Kim, Suh ve Eves, 2010: 217).

\subsection{Gıda Korkusu}

İnsanlar, diğer omnivorlar (hem etçil hem otçul) ile birlikte, gıda bakımından yeniliklere karşı şüpheci olarak karakterize edilmiştir. Yeni yiyecekleri yemekten veya bu yiyeceklerden kaçınılmasından duyulan bu isteksizliğin, potansiyel olarak düşmanca bir gıda ortamında koruyucu bir fonksiyona hizmet eden adaptif değere sahip olduğu varsayılmaktadır. Gıda korkusu, bilinmeyen yiyecekleri yememe isteksizliği olarak tanımlanmaktadır (Pliner ve Hobden, 1992: 105).

İnsanların yiyeceklerle ilgili kaygılarının kökeninde neredeyse bütün insanlığın paylaştığı bir özellik olan hem et hem de ot yiyenlerin ikilemi yatmaktadır (Rozin, 1986). Bu yiyecek davranışı, bir kuşaktan diğerine korunmuş, bazı bireyleri yiyecek hakkında son derece seçici kılan, muhtemelen bilinmeyen bir besin kaynağının potansiyel tehlikesinden korunmak amacı ile kullanılan, kalıtsal bir özelliktir (Knaapila ve diğerleri, 2007). Sanayileşme ve küreselleşmeyle birlikte tüketilen gıdaların yetiştirilmesi, taşınması, işlenmesi veya satışı tamamen farklılaşmış ve yaşanan bu değişimler insanların gıda ile ilgili yaşadıkları korkuyu iyice arttırmıştır (Levenstein, 2013).

Turistlerin yiyecek tüketim tercihlerini etkileyen birçok unsur olması ile birlikte yiyecek ile ilgili kişilik özelliklerinden biri olan gıda korkusu kişilerin yiyecek seçimlerinde önemli bir belirleyicidir (Lafraire, Rioux, Giboreau ve Picard, 2016). Gıda korkusu, kelimenin tam anlamıyla "yeni korkusu" anlamına gelir. Yani yeni yiyeceklerden kaçınma olarak tanımlanabilir (Birch, 1999).

Turist deneyimleri genel olarak yenilik arama olarak tanımlanmaktadır (Lee ve Crompton, 1992: 736; Weaver, McCleary, Han ve Blosser, 2009: 573) ve destinasyonların mutfak lezzetlerinin yenilik, macera ve farklı kültürler arayan turistlerin beklentilerini karşılayabileceği düşünülmektedir (Fields, 2002: 45; Hjalager ve Richards, 2002: 247; Long, 2004: 127). Turistler seyahatleri ile daha önce görmedikleri yerlere gidip farklı kültürler, yerler, insanlar ve farklı yiyecekler ile karşılaşmaktadır. Beslenme insanların hayatta kalabilmek için temel ihtiyaçlarından biri olması nedeniyle seyahatleri boyunca daha önce hiç yemedikleri yiyeceklerle karşılaşacak olan turistler için yiyecek tüketimleri önemli bir konudur.

Turizm alanında yapılan bazı araştırmalarda, gıda korkusunun turistlerin yiyecek tercihlerini etkilediği belirtilmiştir. Örneğin, Cohen ve Avieli (2004), yaptıkları çalışmada turistlerin genellikle yabancı yiyecekler ve farklı hazırlama ve pişirme şekillerinden dolayı gittikleri yerlerdeki yiyecekleri deneme konusunda endişeli olduklarını iddia etmektedirler. Bunun yanı sıra, Chang ve diğerleri (2010), turistlerin farklı destinasyonlarda ait oldukları kültürün yeniliğe karşı korku eğilimini desteklediğini belirtmişlerdir. Kim ve diğerleri (2013) ise, çalışmalarında gıda korkusu ve yiyecek tercihi arasında yaş, cinsiyet ve gelir kadar destinasyondaki mutfak kültürünün de etkileyici bir unsur olduğunu belirtmişlerdir.

\subsection{Kültür}

Kültür, insanların yaşam biçimlerini etkilemektedir. İnsanların paylaştıkları ortak anlamlar olarak tanımlanan duygusal reaksiyonları, tipik bilgi ve inançları ile karakteristik davranış kalıplarını içerir (Peter ve Olson, 2008). Kültür, belirli bir grup insanın yaşamındaki tüm işleyişi ve davranışlarını yönlendirir, yiyecek içecek tercihleri de dâhil olmak üzere insanların sosyal olarak standartlaştırılmış faaliyetlerini belirlenmesi üzerinde etkilidir (Atkins, Atkins \& Bowler, 2001; Logue, 1991).

Kültürel değerler tüketicilerin yiyecek seçimini etkilemektedir (Overby, Gardial \& Woodruff, 2004). Kültür, belirli bir bölgede yaşayan insanlara ait kültürel özelliklere göre bölgenin yerel mutfağında yer alan yiyeceklerin, "kabul edilebilir", "egzotik", "yenilebilir" ya da "lezzetli" olarak algılandığını da tanımlar (Long, 2004; Makela, 2000).

Farklı kültürel geçmişe sahip insanlar yiyecekler ile ilgili farklı algılamalar ve deneyimlere sahip olabilir (Rozin Fischler, Imada, Sarubin \& Wrzesniewski, 1999; van Rijswijk, Frewer, Menozzi \& Faioli, 2008; Seegebarth, Behrens, Klarmann, Hennigs \& Scribner, 2016). Uba (1994) çalışmasında Asya ile batı kültürünü birbirinden ayıran en önemli 
özelliğin Asya kültürünün toplulukçuluk geleneğinin öne çıkması olarak nitelendirmiştir. Örneğin; Avrupa ülkelerinde öğlen yemeği alışkanlıkları Türkiye'de ki kadar önemli bir öğün değildir. Hollanda ve İngiltere'de öğlen yemeği menüsü küçük bir sandviç ve bir içecekle geçiştirilirken Türkiye'de bu öğün daha uzun zaman alan ve geniş bir menüye sahiptir. Bir başka örnekte, Amerika'da yolda yürürken yemek bir alışkanlık iken, Japonya'da yürürken yemek yemek ayıp olarak nitelendirilmektedir (Koç, 2013: 376-379).

\subsection{Planlı Davranış Teorisi}

Sosyal psikoloji tabanlı bir kuram olmakla birlikte, birçok farklı disiplinin alanına giren davranışları açıklamada yaygın olarak kullanılan (Cohen ve Hanno, 1993: 227) planlı davranış teorisi, belirli bir ortamda gerçekleşen insan davranışlarını açıklamak ve tahmin etmek amacıyla tasarlanmış bir davranış teorisidir (Küçük, 2011: 148). Bu teoriye göre insanlar akılcı kararlar alırlar ve aldıkları kararları harekete geçirmeden önce bu eylemin sonuçlarını düşünürler (Ajzen ve Fishbein, 1980: 151). Niyetler insan davranışlarının bir öncülüdür (Fishbein ve Ajzen, 1975: 9).

PDT içinde davranışsal niyeti etkileyen üç bileşen vardır (Ajzen, 1991). Bunlardan ilki davranışın ortaya çıkaracağı sonuçların birey için olumlu veya olumsuz olacağına yönelik inançları içeren "tutumlar"dır. PDT ile ilgili yapılan çalışmaların birçoğunda davranışsal niyetin en önemli belirleyicilerinden birinin tutum olduğu sonucuna varılmıştır (Korkmaz ve Sertoğlu, 2013: 147). Tutum; kişisel bir faktör olarak tanımlanmakta ve kişilerin bir davranışı eyleme geçirme konusundaki olumlu ya da olumsuz değerlendirmelerini ifade etmektedir (Küçük, 2011: 150).

İkinci değişken ise, bireyin yaşadığı çevrenin beklentilerini içeren "öznel normlar"dır. Öznel normlar geleneksel olarak hem normatif inançlardan hem de davranışsal niyet tahmin etme motivasyonundan oluşmaktadır. Ajzen (1991: 188), öznel normları "davranışı gerçekleştirmek için algılanan toplumsal baskı" olarak tanımlamıştır. Bir başka tanıma göre ise, davranışı yapacak olan kişi için önemli olan insanların, kurum veya kuruluşların belirli bir davranışın gerçekleşmesinin ya da gerçekleşmemesinin beklentisi içinde olduklarını ifade etmektedir (Erten, 2002: 221). Bu noktada teori zaman kavramının önemine de işaret ederek, tutumların davranışa yönelmesindeki zaman aralığının uzamasıyla birlikte aralarındaki ilişkinin de azalacağını varsayar (Baltaş, 2000: 40).

Teoride yer alan son değişken ise, "algılanan davranışsal kontrol”dür. Algılanan davranışsal kontrol, bir kişinin belirli bir davranışa girme zorluğu veya kolaylıkla algılandığı anlamına gelir (Ajzen, 1991). Başka bir deyişle, genellikle kişinin belirli davranışları ne kadar başarıyla yerine getirdiğine bağlı olarak kendine güven seviyesiyle ilişkili özdeğerlilik kavramına benzer düşünülür (Bandura, 1982: 130; Zint, 2002: 832).

\section{Yöntem ve Bulgular}

\subsection{Araştırma Hipotezleri ve Modeli}

Yapılan çalışmalar incelendiğinde, PDT kapsamında tutum, öznel norm ve algılanan davranışsal kontrolün, davranışsal niyetlerin oluşması üzerinde önemli etkileri olduğu belirtilmektedir (Wang ve Ritchie, 2012; Sparks ve Shepherd, 1992; Vermeir ve Verbeke, 2008; Verma ve Chandra, 2018; Özer, Kement ve Gültekin, 2015; Han, Hsu ve Sheu, 2010; Lam ve Hsu, 2004; Quintal, Lee ve Soutar, 2010; Phetvaroon, 2006; Chang, Zhang, Yu ve Hu, 2018; Shin ve diğerleri, 2018; Kassem ve Lee, 2004; Kim, Reicks ve Sjoberg, 2003; Shin, 2014; Akkuş, 2013; Hsu, 2014; Raygor, 2016; Wenzig ve Gruchmann, 2018; Choe, 2017). Bu noktadan hareketle turistlerin yerel yiyecekleri tüketme niyetleri üzerine tutum, öznel norm ve algılanan davranışsal kontrolün bir etkisi olacağı düşünülmektedir. Dolayısıyla, $\mathrm{H}_{1}, \mathrm{H}_{2}$ ve $\mathrm{H}_{3}$ hipotezleri aşağıdaki şekilde oluşturulmuştur.

$\mathrm{H}_{1}$ : Turistlerin yerel yiyeceklere yönelik tutumlarının yerel yiyecek tüketme niyetleri üzerinde bir etkisi vardır.

$\mathrm{H}_{2}$ : Turistlerin yerel yiyeceklere yönelik öznel normlarının yerel yiyecek tüketme niyetleri üzerinde bir etkisi vardır.

$\mathrm{H}_{3}$ : Turistlerin yerel yiyeceklere yönelik algıladıkları davranışsal kontrollerin yerel yiyecek tüketme niyetleri üzerinde bir etkisi vardır.

Yiyecek tüketimi ve turizm ile ilgili çalışmalar incelendiğinde gıda korkusu, ziyaret edilen bir yerdeki turist yiyecek tercihleri üzerinde önemli bir etken olarak görülmektedir (Chang, Kivela ve Mak, 2010, 2011; Cohen ve Avieli, 2004; Kim Goh ve Jingxue, 2010; Pliner ve Salvy, 2006; Knaapila ve diğerleri, 2007; Ji, Wong, Eves ve Scarles, 2016). Yukarıdaki çalışmalarda da görüldüğü üzere gıda korkusu turistlerin yerel yiyecek tüketimine yönelik davranışsal niyetleri üzerinde düzenleyici bir etkiye sahip olabilecek bir kişilik özelliği olduğu düşünülmektedir. $\mathrm{Bu}$ nedenle, $\mathrm{H}_{4}, \mathrm{H}_{5}$, $\mathrm{H}_{6}$ hipotezleri aşağıdaki şekilde geliştirilmiştir.

$\mathrm{H}_{4}$ : Gıda korkusunun tutumlar ve davranışsal niyet arasındaki ilişkiler üzerinde düzenleyici bir etkisi vardır.

$\mathrm{H}_{5}$ : Gıda korkusunun öznel normlar ve davranışsal niyet arasındaki ilişkiler üzerinde düzenleyici bir etkisi vardır.

$\mathrm{H}_{6}$ : Gıda korkusunun algılanan davranışsal kontrol ve davranışsal niyet arasındaki ilişkiler üzerinde düzenleyici bir etkisi vardır.

Çalışmada yer alan bir diğer değişken olan kültürün, turizm ve yiyecek tüketimi bağlamında incelendiğinde turistlerin yemek tercihleri üzerindeki etkisi bir dizi çalışma tarafından desteklenmektedir (Sheldon ve Fox, 1988; Pizam ve Sussmann, 1995; Rozin ve diğerleri, 1999; Telfer ve Wall, 2000; Torres, 2002; Cohen ve Avieli, 2004; Tse ve Crotts, 2005; Van Rijswijk ve diğerleri, 2008; Chang ve diğerleri, 2010; Seegebarth, Behrens, Klarmann, Hennigs ve Scribner, 2016). Bu bağlamda farklı milliyetler ve kültürlerden gelen turistlerin yerel yiyecekleri tüketme niyetleri üzerinde kültürün düzenleyici bir etkisinin olabileceği düşünülmektedir. $\mathrm{Bu}$ nedenle aşağıdaki $\mathrm{H}_{7}, \mathrm{H}_{8}$ ve $\mathrm{H}_{9}$ hipotezleri geliştirilmiştir. 
$\mathrm{H}_{7}$ : Kültürün tutum ve davranışsal niyet arasındaki ilişkiler üzerinde düzenleyici bir etkisi vardır.

$\mathrm{H}_{8}$ : Kültürün öznel norm ve davranışsal niyet arasındaki ilişkiler üzerinde düzenleyici bir etkisi vardır.

$\mathrm{H}_{9}$ : Kültürün algılanan davranışsal kontrol ve davranışsal niyet arasındaki ilişkiler üzerinde düzenleyici bir etkisi vardir.

$\mathrm{Bu}$ araştırma kapsamında Hofstede tarafından (1980) 5 boyut olarak geliştirilen ve daha sonrasında 6. bir boyut ekleme gereği duyarak son haline getirdiği (Hofstede, Hofstede ve Minkov, 2010) 6 boyutlu kültür modeli esas alınmıştır. $\mathrm{Bu}$ modelde incelenen her bir boyut arasından, kişilerin yiyecek tüketimine etki edebilecek kültürel özellikleri barındıran "Uzun-kısa vadeli kültürel eğilim" ile "toplumsal hoşgörü-kısıtlama kültürel eğilim" boyutları seçilerek aşağıdaki alt hipotezler geliştirilmiştir.

$\mathrm{H}_{7 \mathrm{a}}$ : Uzun-kısa vadeli kültürel eğilimin, tutumlar ve davranışsal niyet arasındaki ilişkiler üzerinde düzenleyici bir etkisi vardır.

$\mathrm{H}_{8 \mathrm{a}}$ : Uzun-kısa vadeli kültürel eğilimin, öznel normlar ve davranışsal niyet arasındaki ilişkiler üzerinde düzenleyici bir etkisi vardır.

$\mathrm{H}_{9 a}$ : Uzun-kısa vadeli kültürel eğilimin, algılanan davranışsal kontrol ve davranışsal niyet arasındaki ilişkiler üzerinde düzenleyici bir etkisi vardır.

$\mathrm{H}_{7 \mathrm{~b}}$ : Toplumsal hoşgörü-kısıtlama kültürel eğilimin, tutumlar ve davranışsal niyet arasındaki ilişkiler üzerinde düzenleyici bir etkisi vardır.

$\mathrm{H}_{8 \mathrm{~b}}$ : Toplumsal hoşgörü-kısıtlama kültürel eğilimin, öznel normlar ve davranışsal niyet arasındaki ilişkiler üzerinde düzenleyici bir etkisi vardır.

$\mathrm{H}_{9 \mathrm{~b}}$ : Toplumsal hoşgörü-kısıtlama kültürel eğilimin, algılanan davranışsal kontrol ve davranışsal niyet arasındaki ilişkiler üzerinde düzenleyici bir etkisi vardır.

$\mathrm{Bu}$ araştırma kapsamında amaca uygun olarak, betimsel ve nedensel araştırma modeli birlikte kullanılmıştır. Betimsel araştırma modeli ile araştırmaya katılan yabancı turistlerin demografik özelliklerinin (yaş, cinsiyet, eğitim durumu, medeni hal, gelir, milliyet) frekans dağılımları yapılacak olup, yerel yiyecekleri tüketmeye yönelik görüşlerinin ortalama değerleri istatistiki olarak analiz edilmiştir. Bunun yanı sıra nedensel araştırma modeli kapsamında, yabancı turistleri yerel yiyecek tüketimine yönelik tutumları, öznel normları ve algılanan davranışsal kontrolleri ile davranışsal niyetleri arasında bir ilişki olup olmadı̆̆ araştırılmıştır.

Araştırmanın amacı doğrultusunda geliştirilen ve araştırma kapsamında test edilen hipotetik araştırma modeli, şekil 1 'de yer almaktadir.

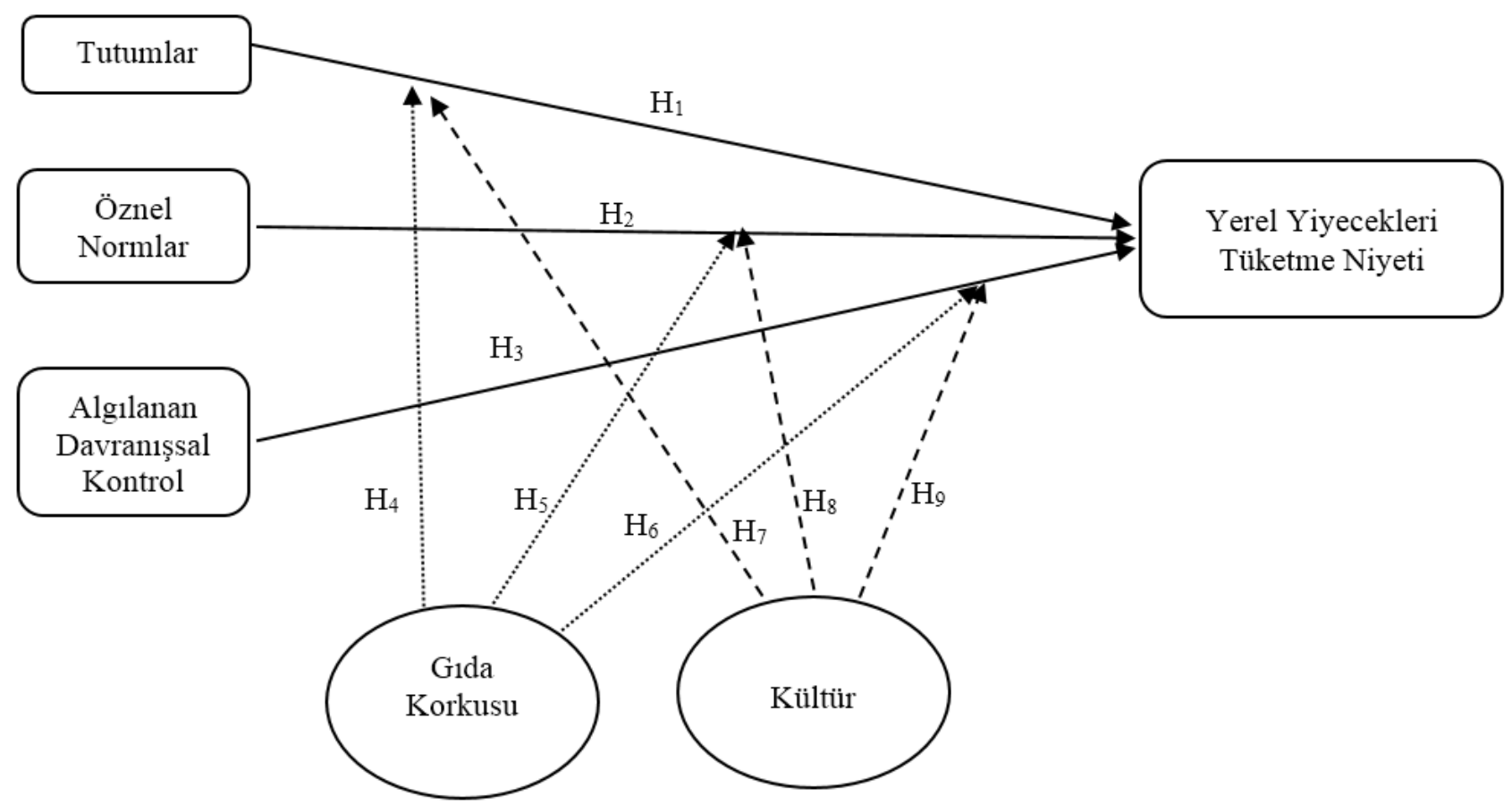

Şekil 1. Hipotetik araştırma modeli

\subsection{Evren Örneklem}

Çalışma kapsamında Türkiye'yi ziyaret eden yabancı ziyaretçilerden veri toplanması aşamasında farklı milliyet ve kültürlerden yabancıların araştırmaya katılması planlanmıştır. İstanbul ve Antalya illeri Türkiye’nin en fazla ziyaret edilen ilk 2 şehridir. Araştırmaya dahil edilen 3. şehir olan Nevşehir'i 2017 yılında ziyaret eden yabancı turistlerin yaklaşık \%70'i Doğu'da bulunan ülkelerden ve kültürlerden gelen turistler oluşmaktadır (Nevşehir İl Kültür ve Turizm Müdürlüğü, 2018). Araştırmaya katılan turistlerin yerel yiyecek tüketimine yönelik milliyetlere göre Avrupalı ve Asyalı turistler arasında bir karşılaştırma yapabilmek için bu iki turist grubundan toplanan anket sayılarının birbirine yaklaşık sayıda 
olması gerekmektedir. Bu nedenle özellikle Nevşehir destinasyonu Asyalı turistlere ulaşabilmek amacıyla araştırmaya dâhil edilmiştir.

Tablo 1. Türkiye'yi Ziyaret Eden Yabancı Turistlerin Sayıları

\begin{tabular}{|l|c|c|c|}
\hline \multirow{2}{*}{ ILLER } & \multicolumn{2}{|c|}{$\begin{array}{c}\text { 2017 } \\
\text { (Ocak-Aralık) }\end{array}$} & $\begin{array}{c}\text { Türkiye'yi ziyaret eden yabancı } \\
\text { sayısı içindeki payı }\end{array}$ \\
\hline Ístanbul & n & \% & \% \\
\hline Antalya & 10.840 .595 & 52,9 & 33,4 \\
\hline Nevşehir & 9.224 .487 & 45,0 & 28,4 \\
\hline Toplam & 391.736 & 2,3 & 1,2 \\
\hline
\end{tabular}

Araştırma kapsamında evrene ilişkin kesin bir liste oluşturulmadığ 1 için olasılıklı örnekleme yöntemlerinde birini tercih etmek mümkün olmamıştır. Araştırmada olasılık dışı örnekleme yöntemlerinden kolayda örnekleme yöntemi ve kota örnekleme yöntemi kullanılmıştır. 2017 yılında Türkiye'yi ziyaret eden toplam yabancı turist sayısı 32.410 .034 olarak belirlenmiştir. Bu sayının \% 40,5'ini Avrupalı turistler oluştururken \% 21,3'ünü ise Asyalı turistler oluşturmaktadır. Çalışma kapsamında Türkiye'yi ziyaret eden yabancı turistlerin milliyetlerine göre geldikleri bölgeler belirlenmiş ve bunun neticesinde Türkiye'nin yabancı turistler tarafından en çok ziyaret edilen iki destinasyonu olan İstanbul ve Antalya ile daha çok Asyalı turistler tarafından ziyaret edilen Nevşehir illerini ziyaret eden yabancı turistler araştırmanın evrenini oluşturmuştur.

Katılımcıların demografik özellikleri incelendiğinde, cinsiyetlerine yönelik dağılım, \% 46,7’nin (301) kadın ve \% 53,3'ün (343) erkek olduğu belirtilmiştir. Yaş gruplarına yönelik dağılımları incelendiğinde \% 12,9'u (83) 18-25 yaş, \% 25’i (161) 26-33 yaş, \% 21,4'ü (138) 34-41 yaş, \% 13,5'in (87) 42-49 yaş, \% 12,6'nın (81) 50-57 yaş ve \% 14,6'nın (94) da 58 ve üzeri yaş aralığında olduğu belirlenmiştir. Turistlerin medeni durumlarına yönelik dağılımlarında \% 61,8 (398) ile çoğunluğun evli olduğu bunun yanı sıra \% 29,8'nin (192) ise bekâr olduğu görülmüştür. Eğitim durumlarına göre dağılımlarda ise, \% 48,9 (315) ile yaklaşık yarısının lisasn düzeyinde eğitim seviyesine sahip iken \% 27,2'nin (175) lise, \% 13,4'ün (86) ön lisans, \% 9,2'nin (59) yüksek lisans ya da doktora ve \%1,4'nün (9) de ilköğretim seviyesinde oldukları anlaşılmaktadır. Çalışmaya katılan yabancıların milliyetlerine ilişkin dağılım incelendiğinde ilk 5 sıra; \% 15,8 (102) Çin, \% 14,3 (92) İngiltere, \% 9,8 (63) Almanya, \% 7,3 (47) Güney Kore ve \% 7 (45) ile Rusya şeklinde oluşmuştur.

\section{3. Ölçme Araçları}

Verilerin toplanması amacıyla hazırlanan anket formu 3 bölümden oluşmaktadır. Birinci bölümde katılımcıların demografik (yaş, cinsiyet, medeni hal, eğitim durumu, yıllık aile gelirleri ve milliyetleri) özelliklerini betimleyen sorular yer almaktadir.

İkinci bölümde ise, katılımcıların yeni ve farklı yiyeceklere yönelik korkularını ölçmek amacıyla Pliner ve Hobden (1992) tarafından geliştirilen gıda korkusu ölçeği (food neophobia scale) kullanılmıştır. Turistlerin yerel yiyecekleri tüketme niyetlerinin belirlenmesi amacıyla çalışmanın temelinin dayandığı ve sosyal psikoloji alanında davranışların belirlenmesinde en çok kullanılan teorilerden biri olan Ajzen (1991) tarafindan geliştirilen PDT kullanılmıştır.

$\mathrm{Bu}$ teori çerçevesinde insanların davranışsal niyetlerinin; tutum, öznel norm ve algılanan davranışsal kontrollerinden oluştukları savunulmaktadır. Anketin üçüncü bölümünde PDT kapsamında turistlerin yerel yiyecekleri tüketme niyetlerine yönelik 9 ifadeden oluşan tutum ölçeği (1: Çok lezzetli-5: Çok lezzetsiz vb.), 6 ifadeden oluşan öznel norm ölçeği, 3 ifadeden oluşan algılanan davranışsal kontrol ölçeği ve 3 ifadeden oluşan davranışsal niyet ölçeği (1: Kesinlikle katılmıyorum-5: Kesinlikle katılıyorum) derecelendirilerek anket tasarımı yapılmıştır.

\subsection{Gıda Korkusu Faktör Analizi}

Gıda korkusunu ölçmek amacıyla Pliner ve Hobden (1992) tarafından geliştirilen gıda korkusu ölçeği kullanılmıştır. Gıda korkusuna ölçeğine ait faktör analizi sonuçları tablo 2'de gösterilmiştir.

Tablo 2. Gıda Korkusu Faktör Analizi Sonuçları

\begin{tabular}{|c|c|c|c|c|c|}
\hline Faktör Ad 1 & İfade No & Faktör Yükü & Özdeğer & $\begin{array}{l}\text { Açılanan } \\
\text { Varyans (\%) }\end{array}$ & Güvenirlik \\
\hline \multirow{4}{*}{ Gida Korkusu } & FN10 & ,812 & \multirow{4}{*}{2,487} & \multirow{4}{*}{62,168} & \multirow{4}{*}{0,796} \\
\hline & FN4 & ,808 & & & \\
\hline & FN6 & ,804 & & & \\
\hline & FN1 & ,728 & & & \\
\hline \multicolumn{3}{|c|}{ Toplam Açıklanan Varyans (\%) } & 62,168 & & \\
\hline \multicolumn{4}{|c|}{ Kaiser-Meyer-Olkin Örneklem Yeterliliği Ölçüsü } & 0,788 & \\
\hline \multicolumn{6}{|c|}{ Bartlett Küresellik Testi } \\
\hline \multicolumn{6}{|c|}{ Ki Kare 752,523; $\quad$ serbestlik derecesi 6; p değeri 0,000} \\
\hline
\end{tabular}


Gıda korkusu ölçeği, temel bileşenler analizi ve kaiser normalizasyonu varimax dik döndürme yöntemi kullanılarak faktör analizine tabi tutulmuş ve sonuçları tablo 2'de gösterilmiştir. Yapılan analiz neticesinde faktör yükleri ve ölçü değerleri bakımından geçerliğinin ve güvenirliğinin yüksek olduğu görülmektedir (Faktör yükü> 0,70; Kaiser-MeyerOlkin Örneklem Yeterliliği Ölçüsü> 0,70; Cronbach alpha $>0,70 ; p=0,000)$. Bunun yanı sıra gida korkusu ölçeği toplam varyansın \% 62'sini açıkladı̆̆ı anlaşılmaktadır.

\subsection{Davranışsal Niyet Faktör Analizi}

Katılımcıların yerel yiyecekleri tüketme niyetlerine yönelik davranışsal niyetlerinin belirlenmesi amacıyla Ajzen (1991) tarafından geliştirilen PDT kapsamında yer alan tutum, öznel norm, algılanan davranışsal kontrol ve davranışsal niyet ölçekleri kullanılmıştır. Araştırmada yararlanılan bu teoride yer alan ölçeklere ilişkin faktör analizi sonuçları aşağıda yer alan 3, 4 ve 5 nolu tablolarda açıklanmıştır.

Tablo 3. Davranışa Yönelik Tutum Faktör Analizi Sonuçları

\begin{tabular}{|c|c|c|c|c|c|}
\hline Faktör Adı & İfade No & Faktör Yükü & Özdeğer & $\begin{array}{l}\text { Aç1klanan } \\
\text { Varyans (\%) }\end{array}$ & Güvenirlik \\
\hline \multirow{9}{*}{ Tutum } & T7 & 885 & \multirow{9}{*}{6,295} & \multirow{9}{*}{69,942} & \multirow{9}{*}{0,945} \\
\hline & T6 & 874 & & & \\
\hline & T5 & 872 & & & \\
\hline & T9 & ,859 & & & \\
\hline & $\mathrm{T} 4$ & ,855 & & & \\
\hline & $\mathrm{T} 8$ & ,851 & & & \\
\hline & $\mathrm{T} 2$ & ,824 & & & \\
\hline & T3 & ,751 & & & \\
\hline & $\mathrm{T} 1$ & ,741 & & & \\
\hline \multicolumn{3}{|c|}{ Toplam Açıklanan Varyans (\%) } & \multirow[t]{2}{*}{69,942} & & \\
\hline \multicolumn{3}{|c|}{ Kaiser-Meyer-Olkin Örneklem Yeterliliği Ölçüsü } & & \multicolumn{2}{|l|}{0,936} \\
\hline \multicolumn{6}{|c|}{ Bartlett Küresellik Testi } \\
\hline \multicolumn{6}{|c|}{ Ki Kare 4901,225; $\quad$ serbestlik derecesi $36 ; \quad$ p değeri 0,000} \\
\hline
\end{tabular}

Katılımcıların davranışa yönelik tutumlarını ölçmek için kullanılan tutum ölçeği, temel bileşenler analizi ve kaiser normalizasyonu varimax dik döndürme yöntemi kullanılarak faktör analizine tabi tutulmuş ve sonuçları tablo 3'de gösterilmiştir. Yapılan analiz neticesinde faktör yükleri ve ölçü değerleri bakımından geçerliğinin ve güvenirliğinin yüksek olduğu görülmektedir (Faktör yükü> 0,70; Kaiser-Meyer-Olkin Örneklem Yeterliliği Ölçüsü> 0,70; Cronbach alpha $>0,70 ; p=0,000)$. Bunun yanı sıra tutum ölçeği toplam varyansın \% 70’ini açıklamaktadır.

Tablo 4. Öznel Norm Faktör Analizi Sonuçları

\begin{tabular}{|c|c|c|c|c|c|}
\hline Faktör Adı & İfade No & Faktör Yükü & Özdeğer & $\begin{array}{l}\text { Açılklanan } \\
\text { Varyans (\%) }\end{array}$ & Güvenirlik \\
\hline \multirow{6}{*}{ Öznel Norm } & ÖN4 & ,859 & \multirow{6}{*}{4,045} & \multirow{6}{*}{67,415} & \multirow{6}{*}{0,903} \\
\hline & ÖN3 & ,828 & & & \\
\hline & ÖN6 & 821 & & & \\
\hline & ÖN5 & 820 & & & \\
\hline & ÖN2 & ,809 & & & \\
\hline & ÖN1 & ,787 & & & \\
\hline \multicolumn{3}{|c|}{ Toplam Açıklanan Varyans (\%) } & \multirow[t]{2}{*}{67,415} & & \\
\hline \multicolumn{3}{|c|}{ Kaiser-Meyer-Olkin Örneklem Yeterliliği Ölçüsü } & & \multicolumn{2}{|l|}{0,887} \\
\hline \multicolumn{6}{|c|}{ Bartlett Küresellik Testi } \\
\hline \multicolumn{6}{|c|}{ Ki Kare 2247,$232 ; \quad$ serbestlik derecesi $15 ; \quad$ p değeri 0,000} \\
\hline
\end{tabular}

Katılımcıların öznel normlarını ölçmek için kullanılan öznel norm ölçeği, temel bileşenler analizi ve kaiser normalizasyonu varimax dik döndürme yöntemi kullanılarak faktör analizine tabi tutulmuş ve sonuçları tablo 4'de gösterilmiştir. Yapılan analiz neticesinde faktör yükleri ve ölçü değerleri bakımından geçerliğinin ve güvenirliğinin yüksek olduğu görülmektedir (Faktör yükü> 0,70; Kaiser-Meyer-Olkin Örneklem Yeterliliği Ölçüsü> 0,70; Cronbach alpha> 0,70; $=0,000)$. Bunun yanı sıra öznel norm ölçeği toplam varyansın \% 67'ini açıklamaktadır. 
Işın, A., Ünlüönen, K. / Journal of Yasar University, 2020, 15/59, 461-479

Tablo 5. Algılanan Davranışsal Kontrol Faktör Analizi Sonuçları

\begin{tabular}{|c|c|c|c|c|c|}
\hline Faktör Ad1 & İfade No & Faktör Yükü & Özdeğer & $\begin{array}{l}\text { Açıklanan } \\
\text { Varyans (\%) }\end{array}$ & Güvenirlik \\
\hline Algilanan & ADK3 & 870 & & & \\
\hline Davranışsal & ADK1 & 849 & 2,185 & 72,822 & 0,811 \\
\hline Kontrol & ADK2 & 841 & & & \\
\hline \multicolumn{3}{|c|}{ Toplam Açıklanan Varyans (\%) } & 72,822 & & \\
\hline \multicolumn{4}{|c|}{ Kaiser-Meyer-Olkin Örneklem Yeterliliği Ölçüsü } & 0,713 & \\
\hline \multicolumn{6}{|c|}{ Bartlett Küresellik Testi } \\
\hline \multicolumn{6}{|c|}{ Ki Kare 654,547; serbestlik derecesi 3; p değeri 0,000} \\
\hline
\end{tabular}

Katılımcıların algıladıkları davranışsal kontrollerini ölçmek için kullanılan algılanan davranışsal kontrol ölçeği, temel bileşenler analizi ve kaiser normalizasyonu varimax dik döndürme yöntemi kullanılarak faktör analizine tabi tutulmuş ve sonuçları tablo 5'te gösterilmiştir. Yapılan analiz neticesinde faktör yükleri ve ölçü değerleri bakımından geçerliğinin ve güvenirliğinin yüksek olduğu görülmektedir (Faktör yükü> 0,70; Kaiser-Meyer-Olkin Örneklem Yeterliliği Ölçüsü> 0,70; Cronbach alpha> 0,70; $\mathrm{p}=0,000$ ). Bunun yanı sıra algılanan davranışsal kontrol ölçeği toplam varyansın \% 73’ünü açıklamaktadır.

\begin{tabular}{|c|c|c|c|c|c|}
\hline Faktör Adı & İfade No & Faktör Yükü & Özdeğer & $\begin{array}{l}\text { Açıklanan } \\
\text { Varyans (\%) }\end{array}$ & Güvenirlik \\
\hline $\begin{array}{l}\text { Davranışsal } \\
\text { Niyet }\end{array}$ & $\begin{array}{l}\text { DN2 } \\
\text { DN3 } \\
\text { DN1 }\end{array}$ & $\begin{array}{l}\text {,933 } \\
\text { 914 } \\
\text { 889 }\end{array}$ & 2,497 & 83,245 & 0,899 \\
\hline \multicolumn{3}{|c|}{ Toplam Açılanan Varyans (\%) } & 83,245 & & \\
\hline \multicolumn{4}{|c|}{ Kaiser-Meyer-Olkin Örneklem Yeterliliği Ölçüsü } & 0,736 & \\
\hline \multicolumn{6}{|c|}{ Bartlett Küresellik Testi } \\
\hline
\end{tabular}

Katılımcıların davranışsal niyetlerini belirlemek için kullanılan davranışsal niyet ölçeği, temel bileşenler analizi ve kaiser normalizasyonu varimax dik döndürme yöntemi kullanılarak faktör analizine tabi tutulmuş ve sonuçları tablo 6'da gösterilmiştir. Yapılan analiz neticesinde faktör yükleri ve ölçü değerleri bakımından geçerliğinin ve güvenirliğinin yüksek olduğu görülmektedir (Faktör yükü> 0,70; Kaiser-Meyer-Olkin Örneklem Yeterliliği Ölçüsü> 0,70; Cronbach alpha $>0,70 ; \mathrm{p}=0,000)$. Bunun yanı sıra davranışsal niyet ölçeği toplam varyansın \% 83'ünü açıklamaktadır.

\subsection{Verilerin Analizi}

Bu çalışma kapsamında toplanan veriler SPSS ve AMOS istatistiksel analiz programları kullanılarak analiz edilmiştir. Araştırmada toplanan veriler arasında anketin yarısının ya da yalnızca demografik sorularının cevaplandığı ve bu nedenle eksik bilgilerin bulunduğu anketler ve sürekli aynı derecelerin işaretlendiği anketler araştırmadan çıkarılmıştır.

Yapısal eşitlik modeli uygulamalarının yapılabilmesi için verilerin normal dağılım göstermesi gerekmektedir (Kline, 2011: 114). Bu nedenle herhangi bir analize başlamadan önce verilerin basıklık ve çarpıklık katsayılarının belirlenmesi için gerekli ön testler yapılmıştır (Baloglu ve Usakli, 2017). Normal dağılım gösteren verilerde basıklık ve çarpıklık katsayıları, \pm 2 değeri aralığında olması gerekmektedir (Klein, 2011: 115). Bu çalışmada toplanan verilerin çarpıklık değerlerinin $-1,182$ ile $+0,32$; basıklık değerlerinin ise $-0,819$ ile $+1,070$ arasında olduğu belirlenmiştir. Dolayısıyla, verilerin normal dağılım gösterdiği tespit edilmiştir. Bu aşamadan sonra araştırma verilerine ilişkin tanımlayıcı istatistikler (frekans, yüzde değer, ortalama değerler, standart sapma) yapılarak analiz işlemleri başlamıştır.

Türkiye'yi ziyaret eden yabancı turistlerin yerel yiyecek tüketimine yönelik davranışsal niyetlerinin belirlenmesi amacıyla PDT kapsamında değerlendirilen davranışsal niyet ölçeği için doğrulayıcı faktör analizi uygulanmışıı. Böylece kullanılan ölçeğin yapı güvenirliği, birleşme geçerliği ve ayırt edici geçerliği analiz edilmiştir. Bir sonraki aşamada, yapısal eşitlik modeli için Anderson ve Gerbing (1988) tarafından önerilen iki aşamalı yaklaşım benimsenmiştir. Bunun için, öncelikle "ölçme modeli" ardından "yapısal model" test edilmiştir. Ölçme modelinin test edilmesi ile ölçme modelinde yer alan tüm faktörlerin (tutum, öznel norm, algılanan davranışsal kontrol, davranışsal niyet ve gıda korkusu) yapı güvenirliği, birleşme ve ayırt edici geçerlikleri incelenmiştir. Ayrıca cronbach alpha içsel tutarlılık katsayıları da hesaplanmıştır. En Çok Olabilirlik (Maximum Likelihood) yöntemi kullanılarak gerçekleştirilen yol analizleri ile hipotezler test edilmiştir. Ayrıca daha güvenilir sonuçlar elde etmek amacıyla yapısal model testi için 5000 örneklemli Bootstrap yöntemi de kullanılmış ve böylece \% 95 yanlılık düzeltmeli güven aralıkları (bias corrected confidence intervals) incelenmiştir (Usakli ve Kucukergin, 2018; Uşakl1, 2016).

Çalışmada gıda korkusu; tutum, öznel norm ve algılanan davranışsal kontrol ile davranışsal niyet arasındaki ilişkiler üzerindeki moderatör etkisinin analiz edilebilmesi için öncelikle K-means cluster yöntemi kullanılarak, tüm katılımcılar "gıda korkusu düşük" ve "gıda korkusu yüksek" olmak üzere iki gruba ayrılmışırı. Moderatör etkisi analizi yapılmadan önce, moderatör analizi yapılacak grup dağılımları esas alınarak, ölçme modeline yönelik invaryans (değişmezlik) testi yapılmıştır. Ölç̧me değişmezliği ön şartı sağlandıktan sonra kısmi metrik değişmezlik (partial metric invariance) testi 
yapılmıştır. Moderatör analizi, En Çok Olabilirlik (Maximum Likelihood) yöntemi ile gerçekleştirilmiştir. Ayrıca 5000 örneklemli Bootstrap yöntemi kullanılarak \% 95 yanlılık düzeltmeli güven aralıkları da raporlanmıştır.

Çalışma kapsamında ayrıca kültür faktörüde moderatör değişken olarak analiz edilmiştir. Hofstede tarafindan (1980) 5 boyut olarak geliştirilen ve daha sonrasında 6. bir boyut ekleme gereği duyarak son halini getirdiği (Hofstede, Hofstede ve Minkov, 2010) 6 boyutlu kültür modeli esas alınmıştır. Bu modelde incelenen her bir boyut arasından, kişilerin yiyecek tüketimine etki edebilecek kültürel özellikleri barındıran "uzun-kısa vadeli kültürel eğilim" ile "toplumsal hoşgörükısıtlama kültürel eğilim" boyutları seçilerek araştırmaya katılan turistler kültür modeline göre gruplandırılmıştır. Moderatör etkisi analizi yapılmadan önce, moderatör analizi yapılacak grup dağılımları esas alınarak, ölçme modeline yönelik invaryans (değişmezlik) testinin yapılması gerekmektedir. Ölçme değişmezliği ön şartını geçen kültür faktörü için kısmi metrik değişmezlik (partial metric invariance) testi yapılmıştır. Moderatör analizi, En Çok Olabilirlik (Maximum Likelihood) yöntemi ile gerçekleştirilmiştir. Ayrıca 5000 örneklemli Bootstrap yöntemi kullanılarak \% 95 yanlılık düzeltmeli güven aralıkları da raporlanmıştır.

\section{7. Ölçme Modeli}

$\mathrm{Bu}$ araştırmada, Anderson ve Gerbing (1988) tarafından önerilen iki aşamalı yapısal eşitlik modeli uygulaması benimsendiği için, öncelikle ölçme modeli, ardından ise yapısal model test edilmiştir. Çalışmanın bu bölümünde, araştırma kapsamında toplanan tüm verilerin (n:644) hem PDT yer alan tüm faktörlerin ve gida korkusu faktörünün yapısal olarak desteklenip desteklenmediğini açıklamak için hem de ilgili ölçeklerin yapısal olarak geçerlik ve güvenirliklerini test edebilmek için AMOS yazılımı kullanılarak birinci düzey doğrulayıcı faktör analizi yapılmıştır.

Doğrulayıcı faktör analizinin yapımında en çok olabilirlik yöntemi kullanılmış ve Hair ve diğerleri (2005) tarafından önerilen en az 0,70’lik faktör yükü kriteri benimsenmiştir. İyi tasarlanmış bir ölçekte ifadelerin ilgili boyutu ölçebilmeleri faktör yükleri ile açıklanmaktadır. Bu nedenle çalışmada kullanılan ölçeklerde yer alan her bir ifade için minimum 0,70 faktör yükü olması gerekliliği esas alınmıştır.

Çalışma kapsamında katılımcıların gıda korkusuna yönelik algılamalarını tespit edebilmek için Pliner ve Hobden (1992) tarafından geliştirilen gıda korkusu ölçeğinin orijinali 10 ifadeden oluşmaktadır. Ancak yapılan ilk faktör analizinde, gida korkusunu ölçen altı ifadenin (GK2, GK3, GK5, GK7, GK8, GK9) düşük faktör yüküne sahip olduğu $(<0.70)$ tespit edilmiş ve ilgili ifadeler çıkarılarak, tekrar doğrulayıcı faktör analizi yapılmıştır.

Yapılan ikinci faktör analizi neticesinde, tüm ifadelerin en az 0,70'lik faktör yükü kriterini taşıdığı görülmüştür. İkinci faktör analizi için hesaplanan $\chi 2$ istatistiği 897,891 (df 260) olup, model uyum indeksleri ise şu şekildedir: $\chi 2 / \mathrm{df}=3,453 ; \mathrm{RMSEA}=0,062 ; \mathrm{SRMR}=0,0438 ; \mathrm{NFI}=0,92 ; \mathrm{NNFI}=0,93 ; \mathrm{CFI}=0,95$. Çalışmada geliştirilen ölçme modeline ilişkin faktör yükleri ve t değerleri tablo 7 'de gösterilmiştir.

Tablo 7. Ölçme Modeline Ilişkin Faktör Yükleri ve t Değerleri

\begin{tabular}{|c|c|c|c|}
\hline Faktör Ad1 & İfadeler & Faktör Yükü & $\underline{t}$ değeri \\
\hline \multirow{10}{*}{ Tutumlar } & $\begin{array}{l}\text { Benim için, Türkiye tatilim boyunca deneyimlediğim Türk } \\
\text { geleneksel yemekleri ........... }\end{array}$ & & \\
\hline & Son derece kötü & 0,787 & $--^{a}$ \\
\hline & Son derece beğenilen & 0,779 & $22,806^{* * *}$ \\
\hline & Son derece sevimsiz & 0,715 & $16,957^{* * *}$ \\
\hline & Son derece uyumsuz & 0,829 & $19,359^{* * *}$ \\
\hline & Son derece tercih edilmeyen & 0,853 & $19,892^{* * *}$ \\
\hline & Son derece yenilemez & 0,860 & $19,994^{* * *}$ \\
\hline & Son derece olumsuz & 0,872 & $20,251^{* * *}$ \\
\hline & Son derece keyifli & 0,827 & $19,353^{* * *}$ \\
\hline & Son derece beğenilmeyen & 0,831 & $19,423^{* * *}$ \\
\hline \multirow{6}{*}{ Öznel Norm } & $\begin{array}{l}\text { Seyahatim boyunca Türk yemeklerini deneyeceğim çünkü } \\
\text { ailemden ve arkadaşlarımdan Türk yemekleri ile ilgili çok şey } \\
\text { duydum }\end{array}$ & 0,738 & $--{ }^{a}$ \\
\hline & $\begin{array}{l}\text { Benim için önemli olan birçok insan bu seyahatimde Türk } \\
\text { geleneksel yemeklerini denememi istiyor }\end{array}$ & 0,722 & $17,872^{* * *}$ \\
\hline & $\begin{array}{l}\text { Düşüncelerimi değerlendiren insanlar bu seyahatimde Türk } \\
\text { geleneksel yemeklerini denememi istiyor }\end{array}$ & 0,765 & $19,036^{* * *}$ \\
\hline & $\begin{array}{l}\text { Ailem ve arkadaşlarım bu seyahatim sırasında Türk geleneksel } \\
\text { yemeklerini denememi önerdi }\end{array}$ & 0,842 & $21,072^{* * *}$ \\
\hline & $\begin{array}{l}\text { Düşüncelerimi etkileyen insanların çoğu Türk geleneksel } \\
\text { yemeklerini denemem gerektiğini düşünüyor }\end{array}$ & 0,793 & $19,823^{* * *}$ \\
\hline & $\begin{array}{l}\text { Bu seyahatim esnasında Türk geleneksel yemeklerini denemek } \\
\text { istiyorum, çünkü bu yemekler ailem ve arkadaşlarım arasında } \\
\text { oldukça popüler }\end{array}$ & 0,789 & $19,711^{* * *}$ \\
\hline
\end{tabular}


Işın, A., Ünlüönen, K. / Journal of Yasar University, 2020, 15/59, 461-479

\begin{tabular}{|c|c|c|c|}
\hline \multirow{3}{*}{$\begin{array}{l}\text { Algılanan } \\
\text { Davranışsal Kontrol }\end{array}$} & $\begin{array}{l}\text { Eğer Türk geleneksel yemeklerini denemek istersem önümde } \\
\text { hiçbir engel olmadığını hissediyorum }\end{array}$ & 0,785 & $--^{a}$ \\
\hline & $\begin{array}{l}\text { Nihayetinde Türk geleneksel yemeklerini deneyip denememek } \\
\text { tamamen bana kalmış bir seçenektir }\end{array}$ & 0,711 & $17,264^{* * *}$ \\
\hline & $\begin{array}{l}\text { İnanıyorum ki eğer istersem, Türkiye seyahatimde } \\
\text { geleneksel yemeklerini satın alabilirim }\end{array}$ & 0,809 & $19,252^{* * *}$ \\
\hline \multirow{4}{*}{ Gıda Korkusu } & Yeni ve farklı yiyecekleri sürekli olarak denerim & 0,717 & $--^{a}$ \\
\hline & Farklı ülkelerin yiyeceklerini severim & 0,742 & $13,662^{* * *}$ \\
\hline & Yiyecek partilerinde yeni yiyecekler denerim & 0,726 & $13,514^{* * *}$ \\
\hline & Yeni etnik restoranları denemeyi severim & 0,733 & $13,581^{* * *}$ \\
\hline \multirow{3}{*}{$\begin{array}{l}\text { Yerel Yiyecek } \\
\text { Tüketme Niyeti }\end{array}$} & $\begin{array}{l}\text { Bu seyahat sırasında Türk geleneksel yemeklerini almaya } \\
\text { istekliyim }\end{array}$ & 0,841 & $--^{a}$ \\
\hline & $\begin{array}{l}\text { Bu seyahat sırasında Türk geleneksel yemeklerini almayı } \\
\text { planliyorum }\end{array}$ & 0,897 & $28,100^{* * *}$ \\
\hline & $\begin{array}{l}\text { Bu seyahat sırasında Türk geleneksel yemeklerini almak için } \\
\text { çaba göstereceğim }\end{array}$ & 0,864 & $26,797^{* * *}$ \\
\hline
\end{tabular}

Tablo 8'de yapı geçerliliği ile ilgili analizler incelendiğinde, yapı geçerliği katsayılarının tamamının istenilen düzeyde $(\mathrm{CR} \geq 0,70)$ olduğu görülmektedir. Bunun yanı sıra diğer bir geçerlilik katsayısı olan cronbach alfa içsel tutarlılığına ilişkin değerlerin de $\geq 0,70$ üzerinde olduğu gösterilmektedir. Buradan yerel yiyecek tüketme niyetine yönelik kullanılan ölçeğin yüksek düzeyde güvenilir ve kullanılabilir olduğu anlaşılmaktadır.

Tablo 8. Yerel Yiyecek Tüketme Niyeti Güvenirlik ve Birleşme Geçerliği Analizi

\begin{tabular}{|c|c|c|c|}
\hline Faktör & $\begin{array}{l}\text { Yap1 Güvenirliği } \\
(\mathrm{CR})\end{array}$ & Cronbach alfa $(\alpha)$ & $\begin{array}{ll}\text { Açıklanan } & \text { Ortalama } \\
\text { Varyans (AVE) } & \\
\end{array}$ \\
\hline Tutum & 0,944 & 0,945 & 0,653 \\
\hline Öznel Norm & 0,900 & 0,903 & 0,602 \\
\hline Algılanan Davranışsal Kontrol & 0,813 & 0,811 & 0,592 \\
\hline G1da Korkusu & 0,798 & 0,796 & 0,500 \\
\hline Yerel Yiyecek Tüketme Niyeti & 0,902 & 0,899 & 0,753 \\
\hline
\end{tabular}

Araştırmada kullanılan ölçme modeline ilişkin ayırt edici geçerlik analizi ve yapılar arasındaki korelasyon katsayıları tablo 9'da gösterilmiştir. Buna göre, ölçme modelinde yer alan tüm yapılar için hesaplanan ortalama varyansın karekök değerleri, o yapının diğer yapılarla olan korelasyon katsayısından daha yüksektir ve ölçme modelinin birbiri ile ilgili, fakat aynı zamanda birbirinden farklı, toplam beş yapıdan oluştuğu teyit edilmiştir. Sonuç olarak, ölçme modelinin ayırt edici geçerliğe sahip olduğu anlaşılmaktadır.

Tablo 9. Ölçme Modeli Ayırt Edici Geçerlik ve Faktörler Arası Korelasyon Katsayıları

\begin{tabular}{llllll}
\hline Faktör & 1 & 2 & 3 & 4 & 5 \\
\hline 1. Tutum & $\mathbf{0 , 8 0 8 *}$ & & & & \\
\hline 2. Öznel Norm & 0,477 & $\mathbf{0 , 7 7 6 *}$ & & & \\
\hline 3. Algilanan Davranışsal Kontrol & 0,513 & 0,524 & $\mathbf{0 , 7 7 0 *}$ & & \\
\hline 4. Gida Korkusu & $-0,205$ & $-0,099$ & $-0,105$ & $\mathbf{0 , 7 0 6} *$ & \\
\hline 5. Yerel Yiyecek Tüketme Niyeti & 0,471 & 0,612 & 0,673 & $-0,217$ & $\mathbf{0 , 8 6 8}^{*}$ \\
\hline
\end{tabular}

* Köşegendeki değerler (italik yazılan) açıklanan ortalama varyansın karekökünü, diğer değerler ise faktörler arası korelasyonları göstermektedir.

\subsection{Yaptsal Model}

Ölçme modeli test edildikten sonra, Anderson ve Gerbing (1988) tarafından önerilen yaklaşımın ikinci aşaması olan yapısal modelin testi (yol analizi) aşamasına geçilmiştir. Yapısal model analizi neticesinde elde edilen standart beta katsayıları şekil 2'de görülmektedir. Görüldüğü üzere, yerel yiyecek tüketme niyetine yönelik davranışsal niyeti etkileyen öznel norm $(\beta=0,336 ; p \leq 0,001)$ ve algılanan davranışsal kontrol $(\beta=0,457 ; p \leq 0,001)$ faktörlerinin istatistiksel olarak anlamlı olduğu, tutum faktörünün $(\beta=0,075)$ ise $\% 10$ düzeyinde anlamlı olduğu belirlenmiştir. 


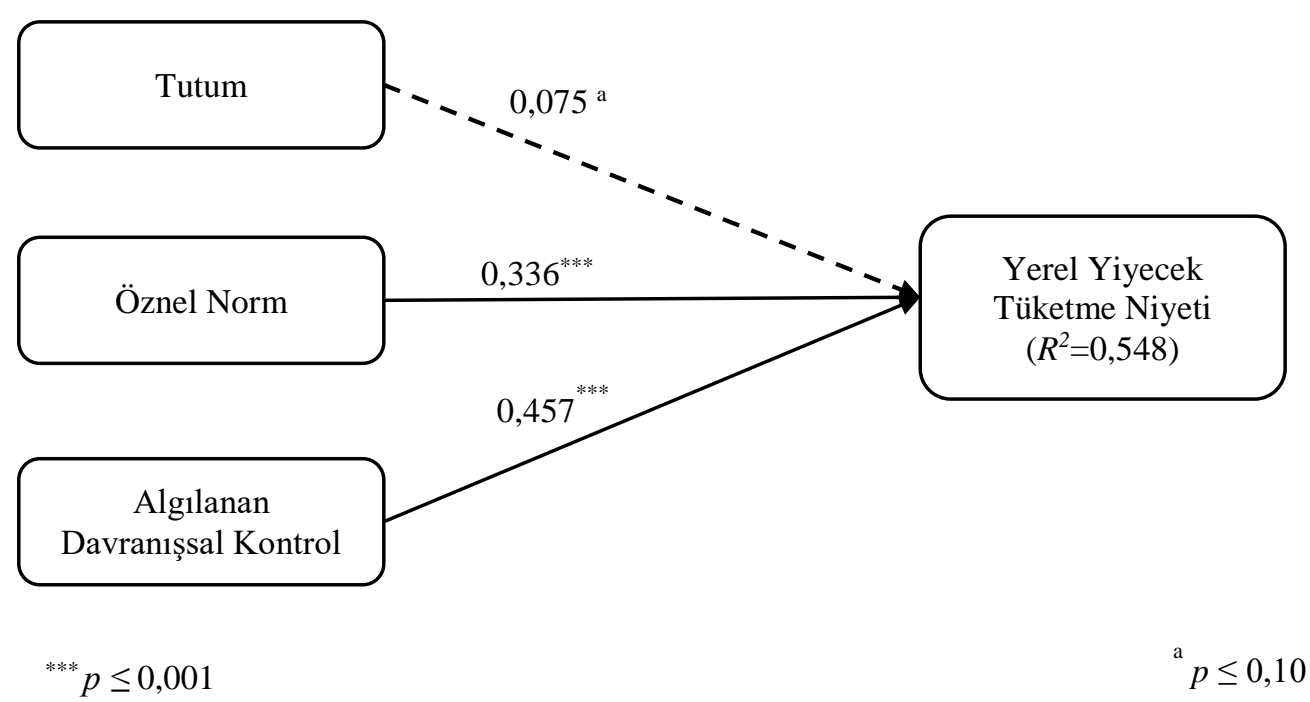

Şekil 2. Yapısal Modele Ilişkin Standart Yol (Beta) Katsayıları

Tablo 10 incelendiğinde, planlı davranış teorisine göre tutum, öznel norm ve algılanan davranışsal kontrolün davranışsal niyetler üzerinde olumlu etkisi olduğu görülmektedir. Dolayısıyla, yabancı turistlerin Türkiye ziyaretleri süresinde yerel yiyecek tüketimine yönelik davranışsal niyetleri ile tutum, öznel norm ve algıladıkları davranışsal kontrol arasında önemli bir ilişkinin var olduğu söylenebilir.

$\mathrm{Bu}$ durumda araştırma kapsamında geliştirilen $\mathrm{H}_{2}$ (turistlerin yerel yiyeceklere yönelik öznel normlarının yerel yiyecek tüketme niyetleri üzerinde olumlu bir etkisi vardır) ve $\mathrm{H}_{3}$ (turistlerin yerel yiyeceklere yönelik algıladıkları davranışsal kontrollerin yerel yiyecek tüketme niyetleri üzerinde olumlu bir etkisi vardır) hipotezleri kabul edilmektedir $(\mathrm{p}<0,05)$.

$\mathrm{H}_{1}$ (turistlerin yerel yiyeceklere yönelik tutumlarının yerel yiyecek tüketme niyetleri üzerinde olumlu bir etkisi vardır) hipotezi ise, $\mathrm{p}<0,10$ anlamlılık düzeyinde kabul edilmektedir. Yapısal eşitlik modeli uygulamalarında nadiren de olsa \% 10 anlamlılık $(\mathrm{p} \leq 0,10)$ düzeyinin bazı çalışmalarda (Matzler ve diğerleri, 2016) halen kullanıldığ 1 görülmektedir.

Beta $(\beta)$ katsayıları incelendiğinde ise, davranışsal niyet üzerindeki en etkili faktörün algılanan davranışsal kontrol $(\beta=0,457)$ olduğu belirlenmiştir. Bunu $(\beta=0,336)$ beta katsayısı ile öznel norm faktörü izlemektedir. Son olarak tutum faktörünün $(\beta=0,075)$ az da olsa davranışsal niyet üzerinde bir etkisinin olduğu söylenebilir.

Tablo 10. Yapısal Modele Ilişkin Bulgular

\begin{tabular}{|c|c|c|c|c|c|c|}
\hline Neden-Sonuç İlişkileri & & & Beta & $t$ değeri & $p$ & \% 95 YD GA \\
\hline Tutum & $\rightarrow$ & $\begin{array}{l}\text { Yerel Yiyecek } \\
\text { Tüketme Niyeti }\end{array}$ & 0,075 & $1,666^{a}$ & 0,092 & $\begin{array}{l}\text { AS: }-0,012 \\
\text { ÜS: } 0,162\end{array}$ \\
\hline Öznel Norm & $\rightarrow$ & $\begin{array}{lc}\text { Yerel } & \text { Yiyecek } \\
\text { Tüketme Niyeti }\end{array}$ & 0,336 & $6,588^{* * *}$ & 0,000 & $\begin{array}{l}\text { AS: } 0,238 \\
\text { ÜS: } 0,437\end{array}$ \\
\hline Davranışsal & $\rightarrow$ & $\begin{array}{lcl}\text { Yerel } & \text { Yiyecek } \\
\text { Tüketme Niyeti }\end{array}$ & 0,457 & $7,370^{* * *}$ & 0,000 & $\begin{array}{l}\text { AS: } 0,331 \\
\text { ÜS: } 0,574\end{array}$ \\
\hline
\end{tabular}

\subsection{Gıda Korkusunun Moderatör Etkisi}

Bu araştırma kapsamında Türkiye’yi ziyaret eden yabancı turistlerin yerel yiyecek tüketimine yönelik davranışsal niyetlerini ölçmek amacıyla PDT kullanılmıştır. Bu teori kapsamında tutum, öznel norm ve algılanan davranışsal kontrolün davranışsal niyet üzerindeki etkisi incelenmiştir. Gıda korkusu, PDT ölçeğinde tutum, öznel norm ve algılanan davranışsal kontrol faktörleri ile davranışsal niyet arasında moderatör değişken olarak analiz edilmiştir. Öncelikle Kortalamalar kümeleme yöntemi kullanılarak, araştırmaya katılan 644 katılımcı gıda korkusu düşük olanlar (n=398) ve gıda korkusu yüksek olanlar (n=) 246 olmak üzere iki gruba ayrılmıştır.

Bunun ardından, kısmi metrik değişmezlik (partial metric invariance) testi yapılmıştır. "Gıda korkusu düşük” ve "gıda korkusu yüksek" katılımcı grupları için yapılan kısmi metrik değişmezlik testi sonucu istatistiksel olarak anlamlı değildir ( $\Delta \chi 2$ 19,4; $\Delta$ df 16, p=0,248). Dolayısıyla, her iki grup için ölçme değişmezliği önkoşulu sağlanmış olup, moderatör analizine geçilmiştir.

Tablo 11'de gıda korkusu faktörünün davranışsal niyet oluşumundaki moderatör etkisi gösterilmektedir. Gruplar arası fark incelendiğinde tutum ve davranışsal niyet arasındaki ilişkinin gıda korkusu faktörüne göre değiştiği belirlenmiştir $(\Delta \beta=0,299 ; \mathrm{p}=0,005)$. Daha açık bir ifade ile tutumun davranışsal niyet üzerindeki etkisi, gida korkusu yüksek olan 
bireylerde $(\beta=0,264)$, tutumun, yerel yiyecek tüketme niyeti üzerindeki etkisi; gıda korkusu düşük olanlara $(\beta=-0,035)$ göre daha fazladır. Dolayısıyla $\mathrm{H}_{4}$ (gıda korkusunun tutumlar ve davranışsal niyet arasındaki ilişkiler üzerinde düzenleyici bir etkisi vardır) hipotezi kabul edilmiştir.

Benzer şekilde gruplar arası farka göre algılanan davranışsal kontrol ve davranışsal niyet arasındaki ilişkininin gıda korkusu moderatör etkisi olduğu tespit edilmiştir $(\Delta \beta=0,289 ; \mathrm{p}=0,038)$. Buna göre, gıda korkusu yüksek olan bireylerde $(\beta=0,330)$, algılanan davranışsal kontrolün, yerel yiyecek tüketme niyeti üzerindeki etkisi; gıda korkusu düşük olanlara $(\beta=0,619)$ göre daha fazla olduğu belirlenmiştir. $\mathrm{Bu}$ nedenle $\mathrm{H}_{6}$ (gıda korkusunun algılanan davranışsal kontrol ve davranışsal niyet arasındaki ilişkiler üzerinde düzenleyici bir etkisi vardır) hipotezi kabul edilmiştir.

Ancak öznel norm ve davranışsal niyet arasındaki ilişkininin gıda korkusu herhangi bir moderatör etkisi tespit edilememiştir $(\Delta \beta=0,166)$. Sonuç olarak $\mathrm{H}_{5}$ (gıda korkusunun öznel norm ve davranışsal niyet arasındaki ilişkiler üzerinde düzenleyici bir etkisi vardır) hipotezi kabul edilememiştir.

Tablo 11. Gida Korkusunun Moderatör Etkisi

\begin{tabular}{|c|c|c|c|c|c|c|c|c|}
\hline \multicolumn{4}{|c|}{ NEDEN-SONUÇ İLİŞKİLERİ } & \multirow{2}{*}{$\begin{array}{l}\begin{array}{l}\text { G1da } \\
\text { korkusu } \\
\text { düşük } \\
(\mathrm{n}=398)\end{array} \\
\text { Beta }\end{array}$} & \multirow{2}{*}{ 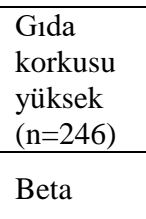 } & \multicolumn{3}{|c|}{ GRUPLAR ARASI FARK } \\
\hline & & & & & & Beta fark1 & $\begin{array}{lll}\% & 95 & \text { YD } \\
\text { GA } & & \end{array}$ & Moderatör Etkileri \\
\hline Tutum & $\rightarrow$ & $\begin{array}{l}\text { Yerel } \\
\text { Tüketme }\end{array}$ & $\begin{array}{l}\text { Yiyecek } \\
\text { Niyeti }\end{array}$ & $-0,035$ & $0,264 * *$ & $0,299 * *$ & $\begin{array}{l}\text { AS: }-0,530 \\
\text { ÜS: }-0,095 \\
\end{array}$ & $\begin{array}{l}\text { G1da Korkusu Yüksek > } \\
\text { Gıda Korkusu Düsük }\end{array}$ \\
\hline Öznel Norm & $\rightarrow$ & $\begin{array}{l}\text { Yerel } \\
\text { Tüketme }\end{array}$ & $\begin{array}{l}\text { Yiyecek } \\
\text { Niyeti }\end{array}$ & $0,276^{* * *}$ & $0,442 * * *$ & 0,166 & $\begin{array}{l}\text { AS: }-0,522 \\
\text { ÜS: } 0,103\end{array}$ & --- \\
\hline $\begin{array}{l}\text { Algilanan } \\
\text { Davranı̧ssal } \\
\text { Kontrol }\end{array}$ & $\rightarrow$ & $\begin{array}{l}\text { Yerel } \\
\text { Tüketme }\end{array}$ & $\begin{array}{l}\text { Yiyecek } \\
\text { Niyeti }\end{array}$ & $0,619 * * *$ & $0,330 * * *$ & $0,289 *$ & $\begin{array}{l}\text { AS: } 0,015 \\
\text { ÜS: } 0,574\end{array}$ & $\begin{array}{l}\text { G1da Korkusu Yüksek > } \\
\text { G1da Korkusu Düşük }\end{array}$ \\
\hline
\end{tabular}

$* \mathrm{p} \leq 0,05 ; * * \mathrm{p} \leq 0,01 ; * * * \mathrm{p} \leq 0,001$

Not: $\quad$ Gruplar Arası Fark = (Gıda korkusu düşük $)-($ Gıda korkusu yüksek $)$

Beta fark1: Mutlak değer cinsinden beta fark1

\%95 YD GA: \%95 Yanlılık Düzeltmeli Güven Aralığı; AS: Alt Sınır; ÜS: Üst Sınır

\subsection{Kültürün Moderatör Etkisi}

$\mathrm{Bu}$ çalışmada kültürün, tutumlar, öznel normlar, algılanan davranışsal kontrol ve davranışsal niyet arasındaki ilişkiler ( $a=$ tutum ve niyet, $b=$ öznel norm ve niyet, $c=$ algılanan davranışsal kontrol ve niyet) üzerinde düzenleyici bir etkisi hipotezini test etmek amacıyla Hofstede tarafından (1980) 5 boyut olarak geliştirilen ve sonrasında 6. B ir boyut ekleme gereği duyarak son halini getirdiği (Hofstede, Hofstede ve Minkov, 2010) 6 boyutlu kültür modeli esas alınmıştır. Bu modelde incelenen her bir boyut arasından, kişilerin yiyecek tüketimine etki edebilecek kültürel özellikleri barındıran "Uzun-kısa vadeli kültürel eğilim” ile "Toplumsal hoşgörü-kısıtlama kültürel eğilim” boyutları seçilmiştir. Araştırmaya 47 farklı milliyetten 644 yabancı turist katılmıştır. Katılımcılar, belirlenen boyutlar doğrultusunda Hofstede’nin ülkeleri gruplandırmasına göre sınıflandırılmışlardır.

\subsubsection{Kısa-Uzun Vadeli Yönelim Kültür Boyutuna Göre Moderatör Analizi}

Tablo 12'de yer alan gruplar arası fark incelendiğinde, kısa-uzun vadeli yönelim kültür boyutunun tutum ve davranışsal niyet ilişkileri üzerinde moderatör bir etkisi bulunmamıştır $(\Delta \beta=0,168)$. Benzer şekilde kısa-uzun vadeli yönelim kültür boyutu öznel norm ve davranışsal niyet $(\Delta \beta=0,036)$ ile algılanan davranışsal kontrol ile davranışsal niyet ilişkileri $(\Delta \beta=0,095)$ üzerinde de moderatör bir etkisi bulunmamıştır. Dolayısıyla, $\mathrm{H}_{7}$ a (uzun-kısa vadeli kültürel eğilimin, tutumlar ve davranışsal niyet arasındaki ilişkiler üzerinde düzenleyici bir etkisi vardır), $\mathrm{H}_{8}$ a (uzun-kısa vadeli kültürel eğilimin, öznel normlar ve davranışsal niyet arasındaki ilişkiler üzerinde düzenleyici bir etkisi vardır) ve $\mathrm{H}_{9}$ a (uzun-kısa vadeli kültürel eğilimin, algılanan davranışsal kontrol ve davranışsal niyet arasındaki ilişkiler üzerinde düzenleyici bir etkisi vardır) hipotezleri kabul edilememiştir.

Tablo 12. Kısa-Uzun Vadeli Yönelim Kültür Boyutunun Moderatör Etkisi

\begin{tabular}{|c|c|c|c|c|c|c|c|}
\hline \multirow{2}{*}{\multicolumn{3}{|c|}{ NEDEN-SONUÇ İLIŞSİLERİ }} & $\begin{array}{l}\text { Kisa } \\
\text { vadeli } \\
\text { yönelim } \\
(n=101)\end{array}$ & $\begin{array}{l}\text { Uzun } \\
\text { vadeli } \\
\text { yönelim } \\
(n=506)\end{array}$ & \multicolumn{3}{|c|}{ GRUPLAR ARASI FARK } \\
\hline & & & Beta & Beta & Beta fark1 & $\begin{array}{lll}\% & 95 & \text { YD } \\
\text { GA } & & \end{array}$ & Moderatör Etkileri \\
\hline Tutum & $\rightarrow$ & $\begin{array}{l}\text { Yerel Yiyecek } \\
\text { Tüketme Niyeti }\end{array}$ & 0,013 & $0,182 * *$ & 0,168 & $\begin{array}{l}\text { AS: }-0,433 \\
\text { ÜS: } 0,096\end{array}$ & -- \\
\hline Öznel Norm & $\rightarrow$ & $\begin{array}{l}\text { Yerel Yiyecek } \\
\text { Tüketme Niyeti }\end{array}$ & $0,296 * * *$ & $0,331 * * *$ & 0,036 & $\begin{array}{l}\text { AS: }-0,249 \\
\text { ÜS: } 0,190\end{array}$ & --- \\
\hline
\end{tabular}


Işın, A., Ünlüönen, K. / Journal of Yasar University, 2020, 15/59, 461-479

\begin{tabular}{llllllll}
\hline $\begin{array}{l}\text { Algılanan } \\
\text { Davranışsal } \\
\text { Kontrol }\end{array}$ & $\rightarrow$ & $\begin{array}{l}\text { Yerel } \\
\text { Tüketme Niyeti }\end{array}$ & $0,531^{* * *}$ & $0,436^{* * *}$ & 0,095 & $\begin{array}{l}\text { AS: }-0,148 \\
\text { ÜS: } 0,330\end{array}$ & --- \\
\hline
\end{tabular}

\subsubsection{Hoşgörü-Kısıtlama Kültür Boyutuna Göre Moderatör Analizi}

Tablo 13'de yer alan gruplar arası fark incelendiğinde, hoşgörü-kısıtlama kültür boyutunun öznel norm ve davranışsal niyet ilişskileri üzerinde moderatör bir etkisinin olduğu tespit edilmiştir $(\Delta \beta=0,172 ; p=0,045)$. Buna göre, $\mathrm{H}_{8} \mathrm{~b}$ (toplumsal hoşgörü-kısıtlama kültürel eğilimin, öznel normlar ve davranışsal niyet arasındaki ilişkiler üzerinde düzenleyici bir etkisi vardır) kabul edilmiştir. Dolayısıyla, kısıtlı kültür grubunda yer alan bireylerde, öznel normların, yerel yiyecek tüketme niyeti üzerindeki etkisi; anlayışlı kültür grubunda yer alanlara göre daha fazladır.

Hoşgörü-kısıtlama kültür boyutu tutum ve davranışsal niyet üzerinde de moderatör bir etkisi bulunamamıştır. Ancak kısıtlı kültür grubundakiler için, tutumun, niyet üzerindeki etkisi anlamlıdır (beta=0,149*). Diğer yandan, anlayışlı kültür grubundakiler için, tutumun, niyet üzerinde anlamlı etkisi bulunamamıştır. Ancak aralarında etki farklılaşması var demek için bu sonuç yeterli değildir. Çünkü neticesinde, moderatör etkisi anlamsız çıkmıştır $(\Delta \beta=0,030)$. Son olarak hoşgörükısıtlama kültür boyutu ile algılanan davranışsal kontrol ile davranışsal niyet ilişkileri $(\Delta \beta=0,006)$ üzerinde de moderatör bir etkisi bulunamamıştır. Dolayısıyla, $\mathrm{H}_{7}$ b (toplumsal hoşgörü-kısıtlama kültürel eğilimin, tutumlar ve davranışsal niyet arasındaki ilişkiler üzerinde düzenleyici bir etkisi vardır) ve $\mathrm{H}_{9}$ b (toplumsal hoşgörü-kısıtlama kültürel eğilimin, algılanan davranışsal kontrol ve davranışsal niyet arasındaki ilişkiler üzerinde düzenleyici bir etkisi vardır) hipotezleri kabul edilememiştir.

Tablo 13. Hoşgörü-Kısıtlama Kültür Boyutunun Moderatör Etkisi

\begin{tabular}{|c|c|c|c|c|c|c|c|}
\hline \multirow{2}{*}{\multicolumn{3}{|c|}{ NEDEN-SONUÇ İLİŞKİLERİ }} & \multirow{2}{*}{$\begin{array}{l}\begin{array}{l}\text { Kisitl1 } \\
(n=413)\end{array} \\
\text { Beta }\end{array}$} & \multirow{2}{*}{$\begin{array}{l}\begin{array}{l}\text { Anlayışl1 } \\
(\mathrm{n}=194)\end{array} \\
\text { Beta }\end{array}$} & \multicolumn{3}{|c|}{ GRUPLAR ARASI FARK } \\
\hline & & & & & Beta fark1 & $\begin{array}{l}\% 95 \quad \mathrm{YD} \\
\mathrm{GA}\end{array}$ & Moderatör Etkileri \\
\hline Tutum & $\rightarrow$ & $\begin{array}{l}\text { Yerel Yiyecek } \\
\text { Tüketme Niyeti }\end{array}$ & $0,149^{*}$ & 0,119 & 0,030 & $\begin{array}{l}\text { AS: }-0,190 \\
\text { ÜS: } 0,246\end{array}$ & --- \\
\hline Öznel Norm & $\rightarrow$ & $\begin{array}{l}\text { Yerel Yiyecek } \\
\text { Tüketme Niyeti }\end{array}$ & $0,354 * * *$ & $0,182 *$ & $0,172 *$ & $\begin{array}{l}\text { AS: } 0,062 \\
\text { ÜS: } 0,405 \\
\end{array}$ & Kısıtlı > Anlayışlı \\
\hline $\begin{array}{l}\text { Algilanan } \\
\text { Davranışsal } \\
\text { Kontrol }\end{array}$ & $\rightarrow$ & $\begin{array}{l}\text { Yerel Yiyecek } \\
\text { Tüketme Niyeti }\end{array}$ & $0,482 * * *$ & $0,476^{* * *}$ & 0,006 & $\begin{array}{l}\text { AS: }-0,264 \\
\text { ÜS: } 0,269\end{array}$ & --- \\
\hline
\end{tabular}

\section{Sonuç ve Öneriler}

Araştırmada yabancı turistlerden toplanan veriler ve analizler neticesinde PDT’ye uygun olarak tutum, öznel norm ve algılanan davranışsal kontrolün davranışsal niyeti etkilediği tespit edilmiştir. Elde edilen veriler literatürde yer alan çalışmaları destekler niteliktedir (Conner, Norman ve Bell, 2002; Kim, Reicks ve Sjoberg, 2003; Vermeir ve Verbeke, 2008; Hsu, 2014; Verbeke ve Vackier, 2005; Choe, 2017; Kassem ve Lee, 2004; Dunn, 2008).

Çalışmada, gıda korkusu ve kültür faktörleri turistlerin yerel yiyecek tüketimine yönelik tutum, öznel norm ve algılanan davranışsal kontrol ile davranışsal niyetleri arasında moderatör değişken olarak test edilmiştir. Gıda korkusunun ölçülmesi için kullanılan ve orjinalinde 10 ifadeden oluşan gıda korkusu ölçeği (Pliner ve Hobden, 1992) analizlere başında yapılan doğrulayıcı faktör analizi neticesinde 4 ifadeye düşürülmüştür. Kalan 4 ifade K-ortalamalar kümeleme yöntemi kullanılarak turistler, gıda korkusu düzeyi düşük ve yüksek olmak üzere iki gruba ayrılmışlardır.

Gıda korkusu yüksek olan bireylerde tutumun davranışsal niyet üzerindeki etkisi, gıda korkusu düşük olanlara göre daha fazladır. Bu sonuç literatürde yer alan bazı çalışmalar ile benzerlik göstermektedir (Cook ve diğerleri, 2002; Han ve Kim, 2010; Quintal ve diğerleri, 2010; Choe, 2017).

Benzer şekilde, algılanan davranışsal kontrol ve davranışsal niyet arasındaki ilişkide gıda korkusumoderatör etkisine sahiptir. Gıda korkusu yüksek olan bireylerde algılanan davranışsal kontrolün, yerel yiyecek tüketme niyeti üzerindeki etkisi; gıda korkusu düşük olanlara göre daha fazladır. Bu sonuçlar (Astrom ve Rise, 2001; Hsu, 2014) çalışması ile benzerlik göstermektedir. Gıda korkusunun, yerel yiyecek tüketiminde önemli bir düzenleyici değişken olduğu söylenebilir. Ancak gıda korkusu faktörünün öznel norm ve davranışsal niyet ilişkisi üzerinde herhangi bir moderatör etkisi olmadı̆̆ı tespit edilmiştir.

Bir diğer moderatör değişken olan kültürün kullanımında ise Hofstede tarafindan geliştirilen (1980, 2010) 6 boyutlu kültür modeli tercih edilmiştir. Hofstede'nin sınıflamasına göre 6 kültür boyutu içerisinden, kişilerin yiyecek tüketimine etki edebilecek kültürel özellikleri barındıran "uzun-kısa vadeli kültürel eğilim" ile "toplumsal hoşgörü-kısıtlama kültürel eğilim" boyutlarının tutum, öznel norm ve algılanan davranışsal kontrol ile davranışsal niyet arasında düzenleyici bir etkisi olup olmadığı test edilmiştir. Buna göre tutum ve davranışsal niyet, öznel norm ve davranışsal niyet, algılanan davranışsal kontrol ve davranışsal niyet arasında uzun-kısa vadeli kültürel eğilimin moderatör bir etkisinin olmadığı belirlenmiştir.

Moderatör değişken olarak kullanılan bir diğer kültür boyutu olan toplumsal hoşgörü-kısıtlama kültürel eğilim boyutu ise yalnızca öznel norm ve davranışsal niyet arasında moderatör etkisi tespit edilmiştir. Diğer bir ifade ile kısıtlı kültür 
grubunda yer alan bireylerde, öznel normların, yerel yiyecek tüketme niyeti üzerindeki etkisi; anlayışlı kültür grubunda yer alanlara göre daha fazladır.

Araştırmada gıda korkusu faktörünün turistlerin yerel yiyecek tüketimini kısmen etkilediği sonucuna varılmıştır. Buradan hareketle ülkemizi ziyaret etmeyi planlayan potansiyel yabancı turistlerin Türkiye'nin yerel yiyecekleri ile ilgili olası korkuları ya da önyargılarını azaltmak için uluslararası fuarlarda yiyecekler ile tanıtımların daha etkin bir şekilde gerçekleştirilmesi sağlanabilir. Bunun yanı sıra Türk mutfağını dünyaya tanıtmak için yalnızca uluslararası fuarlarda yapılan tanıtımların yeterli olmadığı düşünülmektedir. Türkiye'nin tanıtımı ve imajının oluşturulmasında ship olduğu mutfak kültürü devlet tarafından bir tanıtım aracı haline getirilmelidir. Örneğin, yurt dışındaki üniversiteler ile anlaşmalar yapılarak özellikle gastronomi ile ilgili bölümlerde Türk mutfağı eğitimi verilmesi sağlanabilir. Bu sayede yabanc1 genç nüfusta Türk mutfağı sayesinde Türkiye ile ilgili olumlu bir imaj oluşabileceği öngörülmektedir.

Çalışma Türkiye'de üç farklı destinasyonda ve belirli sayıdaki (n=644) katılımcıyla birlikte yapılmıștır. Gelecekte daha fazla sayıda destinasyon ve katılımcı ile yapılacak araştırmalar, daha genelleyici ve kapsamlı yorumlar yapılmasına olanak sağlayacaktır. Bunun yanı sıra çalışma kapsamında kültürel olarak yalnızca doğu ve batı kültüründen gelen yabancı turistlerin yerel yiyecek tüketimine yönelik bir karşılaştırma yapılabilmiştir. Gelecek araştırmalarda daha fazla sayıda milliyetten gelen turist gruplarına yönelik yapılacak anket çalışması ile daha farklı bölgeler, örneğin; Amerika, Afrika ya da Orta Doğu gibi, ile kültürel karşılaştırmaların gerçekleştirilmesine olanak sağlayacaktır. 
Işın, A., Ünlüönen, K. / Journal of Yasar University, 2020, 15/59, 461-479

\section{KAYNAKÇA}

Ajzen, Icek, and Fishbein, Martin. 1980. Understanding Attitudes and Predicting Social Behavior, Englewood Cliffs, New Jersey: Prentice Hall.

Ajzen, Icek. 1987. "Attitudes, Traits, and Actions: Dispositional Prediction of Behavior in Personality and Social Psychology.” Advances in Experimental Social Psychology edited by Berkowitz, Leonard, 1-63. Academic Press, New York,

Ajzen, Icek. 1991. The Theory of Planned Behavior, Organizational Behavior and Human Decision Processes, 50: 179211.

Akkuş, Gülşah. 2013. “Yemek turizmine katılma niyeti: Planlı davranış teorisi çerçevesinde bir inceleme”. Doktora Tezi, Erciyes Üniversitesi Sosyal Bilimler Enstitüsü, Kayseri.

Anderson, James C., and Gerbing, David W. 1988. Structural Equation Modeling in Practice: A Review and Recommended Two-Step Approach. Psychological Bulletin, 103(3): 411-423.

Astrom, Anne N., and Rise, Jostein. 2001. Young Adults' Intention to Eat Healthy Food: Extending the Theory of Planned Behaviour. Psychology \& Health, 16(2): 223-237.

Atkins, Peter, and Bowler, Ian. 2001. Food in Society: Economy, Culture, Geography. London: Arnold

Baloğlu, Şeyhmus, and Uşaklı, Ahmet. 2017. "Summarizing Data.” Research Methods for Leisure, Recreation and Tourism (2nd Edition) edited by Sirakaya-Turk, Ercan, Uysal, Muzaffer, Hammit, William E. \& Vaske, Jerry J., 243-268. UK: CABI Publishing.

Baltaş, Zuhal. 2000. Să̆lık Psikolojisi, Halk Sağlı̆̆ında Davranış Bilimleri, İstanbul: Remzi Kitabevi.

Bandura, Albert. 1982. Self-Efficacy Mechanism in Human Agency. American Psychologist, 37(2): 122-147.

Bayrakçı, Selman. 2014. "Yerel Yemek Tüketim Motivasyonlarının Turistlerin Tekrar Ziyaret Niyetlerine Etkisi: Gaziantep’i Ziyaret Eden Yerli Turistler Üzerine Bir Araştırma”, Yüksek lisans tezi, Mersin Üniversitesi, Sosyal Bilimler Enstitüsü, Mersin.

Birch, Leann L. 1999. Development of Food Preference. Annual Review of Nutrition, 19(1): 41-62.

Björk, Peter, and Kauppinen-Räisänen, Hannele. 2016. Local Food: A Source for Destination Attraction, International Journal of Contemporary Hospitality Management, 28 (1): 177-194.

Chang, Richard C. Y., Kivela, Jakša, and Mak, Athena H. N. 2010. Food Preferences of Chinese Tourists. Annals of Tourism Research, 37 (4): 989-1011.

Chang, Richard C. Y., Kivela, Jakša, and Mak, Athena H. N. 2011. Attributes that Influence the Evaluation of Travel Dining Experinece: When East Meets West. Tourism Management, 32 (2): 307-316.

Chang, Wang, Zhang, Jinhe, Yu, Peng, and Hu, Huan. 2018. The Theory of Planned Behavior as a Model for Understanding Tourists' Responsible Environmental Behaviors: The Moderating Role of Environmental Interpretations. Journal of Cleaner Production, 194: 425-434.

Choe, Ja Young. 2017. “Effects of tourists' local food consumption value on attitude towards local food, food destination image and behavioral intention”, Doctoral Dissertation, The Hong Kong Polytechnic University School of Hotel and Tourism Management, Hong Kong.

Choe, Ja Young, and Kim, Seongseop. 2018. Effects of Tourists’ Local Food Consumption Value on Attitude, Food Destination Image, and Behavioral Intention. International Journal of Hospitality Management, 71: 1-10.

Choe, Ja Young, and Kim, Seongseop. 2019. Development and Validation of a Multidimensional Tourist's Local Food Consumption Value (TLFCV) Scale. International Journal of Hospitality Management, 77: 245-259.

Cohen, Jeffrey and Hanno, Dennis M. 1993. An Analysis of Underlying Constructs Affecting the Choice of Accounting as a Major. Issues in Accounting Education, 8(2): 219-238.

Cohen, Erik, and Avieli, Nir. 2004. Food in Tourism: Attraction and Impediment. Annals of Tourism Research, 31(4): 755-778.

Conner, Mark T., Norman Paul, and Bell Russell. 2002. The Theory of Planned Behavior and Healthy Eating. Health Psychology, 21(2): 194-201.

Cook, Andrew J., Kerr, Geoff N., and Moore, Kevin. 2002. Attitudes and Intentions Towards Purchasing GM Food. Journal of Economic Psychology, 23(5): 557-572.

Di Pietro, Robin B., and Campbell, Jeffrey. 2014. The Influence of Servicescape and Local Food Attributes on Pleasure and Revisit Intention in an Upscale-Casual Dining Restaurant, Hospitality Review, 31(4).

Du Rand, Gerrie E., Heath, Ernie, and Alberts, Nic. 2003. The Role of Local and Regional Food in Destination Marketing: A South African Situation Analysis, Journal of Travel \& Tourism Marketing, 14: 97-112.

Dunn, Kirsten. 2008. "Fast Food Consumption: Application and Extension of the Theory of Planned Behaviour to Incorporate Affective Response and Implicit Associations.” Doctoral Thesis, University of Adelaide, School of Psycholgy and Discipline of Medicine, Australia.

Erten, Sinan. 2002. Planlanmış Davranış Teorisi ile Uygulamalı Öğretim Metodu. Hacettepe Üniversitesi Edebiyat Fakültesi Dergisi, 19(2): 217-233.

Fields, Kevin. 2002. “Demand for the Gastronomy Tourism Product: Motivational Factors.” Tourism and Gastronomy edited by Hjalager, Anne-Mette, and Richards, Greg., 37-50, London: Routledge.

Fishbein, Martin, and Ajzen, Icek. 1975. Belief, Attitude, Intention and Behavior: An Introduction to Theory and Research. MA: Addison-Wesley. 
Işın, A., Ünlüönen, K. / Journal of Yasar University, 2020, 15/59, 461-479

Girgin, Göksel Kemal. 2018. Yerel Gıdaların Tüketilmesine Yönelik Turist Motivasyonlarının Ölçülmesi: Antalya’da Bir Uygulama. Atatürk Üniversitesi Sosyal Bilimler Enstitüsü Dergisi, 22 (Özel Sayı): 793-810.

Hair, Joseph F., Black,William C., Babin, Barry J., Anderson, Rolph E. and Tatham, Ronald L. 2005. “Multivariate Data Analysis (6th Edition).” New Jersey: Prentice Hall.

Hall, C. Michael, and Mitchell, Richard. 2005. "Gastronomic Tourism, Comparing Food and Wine Tourism Experiences”, Niche Tourism: Contemporary Issues, Trends and Cases Edited by Novelli, Marina. 73-88. Oxford: Butterworth Heineman.

Han, Heesup, and Kim, Yunhi. 2010. An Investigation of Green Hotel Customers’ Decision Formation: Developing an Extended Model of the Theory of Planned Behavior. International. Journal of Hospitality Management, 29: 659668.

Han, Heesup, Hsu, Li-Tzang Jane, and Sheu. Chwen. 2010. Application of the Theory of Planned Behavior to Green Hotel Choice: Testing the Effect of Environmental Friendly Activities. Tourism Management, 31: 325-334.

Hofstede, Geert. 1980. “Culture's Consequences: International Differences in Work-Related Values”. Beverly Hills, CA: Sage

Hofstede, Geert, Hofstede, Gert Jan, and Minkov, Michael. 2010. "Cultures and Organizations: Software of the Mind (Rev. 3rd edition)”. New York: McGraw-Hill.

Hsu, Fu-Chieh. 2014. “Food Tourism: Consumer Behaviour in Relation to Traditional Food”. Doctoral Dissertation, The University of Queensland, Australia.

Işın, Alper. 2019. "Food Consumption Behaviors of Tourists in the Scope of Gastronomy Tourism”, Current Issues in Tourism and Hospitality Management edited by Yazıcığlu, İrfan, Yayla, Özgür \& Solunoğlu, Ali. 193-206. SRA Academic Publishing: Lithuanian.

Ji, Mingjie, Wong, Ipkin Anthony, Eves, Anita, and Scarles, Caroline. 2016. Food-Related Personality Traits and the Moderating Role of novelty-Seeking in Food Satisfaction and Travel Outcomes. Tourism Management, 57: 387 396.

Khan, Mahmood A., and Hackler, L. R. 1981. Evaluation of Food Selection Patterns and Preferences. Critical Reviews in Food Science and Nutrition, 15: 129-153.

Knaapila, Antti, Tuorila, Hely, Silventoinen, Karri, Keskitalo, Kaisu, Kallela, Mikko, Wessman, Maija, Peltonen, Leena, Cherkas, Lynn F., Spector, Tim D., and Perola, Markus. 2007. Food Neophobia Shows Heritable Variation in Humans. Physiology and Behavior, 91: 573-578.

Kassem Nada O., and Lee Jerry W. 2004. Understanding Soft Drink Consumption Among Male Adolescents Using the Theory of Planned Behavior. Journal of Behavioral Medicine, 27(3): 273-296.

Kim Kyungwon, Reicks, Marla, and Sjoberg, Sara. 2003. Applying the Theory of Planned Behavior to Predict Dairy Product Consumption by Older Adults. Journal of Nutrition Education and Behavior, 35(6): 294-301.

Kim, Yeong Gug, Eves, Anita, and Scarles, Caroline. 2009. Building a Model of Local Food Consumption on Trips and Holidays: A Grounded Theory Approach. International Journal of Hospitality Management, 28 (3): $423-431$.

Kim, Yeong Gug, Suh, Bo Won, and Eves, Anita. 2010. The Relationships Between Food-Related Personality Traits, Satisfaction, and Loyalty Among Visitors Attending Food Events and Festivals. International Journal of Hospitality Management, 29(2): 216-226.

Kim, Young H., Goh. Ben K., and Jingxue, Yuan J. 2010. Development of a Multi-Dimensional Scale for Measuring Food Tourist Motivations. Journal of Quality Assurance in Hospitality \& Tourism, 11 (1): 56- 71.

Kim, Yeong Gug, and Eves, Anita. 2012. Construction and Validation of a Scale to Measure Tourist Motivation to Consume Local Food. Tourism Management, 33(6): 1458-1467.

Kim, Yeong Gug, Eves, Anita, and Scarles, Caroline. 2013. Empirical Verification of a Conceptual Model of Local Food Consumption at a Tourist Destination. International Journal of Hospitality Management, 33: 484-489.

Kim, Seongseop, Choe, Ja Young, and Lee, Aejoo. 2016. Efforts to Globalize a National Food: Market Segmentation by Reasons for Ethnic Food Preferences. International Journal of Contemporary Hospitality Management, 28 (10): 2010-2030.

Kline, Rex B. 2011. "Principles and Practice of Structural Equation Modeling (3rd Edition)”. New York: The Guilford.

Koç, Erdoğan. 2013. “Tüketici Davranışı ve Pazarlama Stratejileri (Global ve Yerel Yaklaşım, 1200'den Fazla Uygulama Örnekli) (5. Baskı)”, Ankara: Seçkin Yayınevi.

Korkmaz, Sezer, ve Sertoğlu, Ayşegül. 2013. Genç Tüketicilerin Sürdürülebilir Gıda Tüketimi Davranışının Güven ve Değerlere Dayanan Planlı Davranış Teorisi Kapsamında Tartışılması. Hacettepe Üniversitesi İktisadi ve İdari Bilimler Fakültesi Dergisi, 31(1): 127-152.

Küçük, Ergün. 2011. Planlanmış Davranış Teorisi Çerçevesinde Mali Müşavir (Smmm) Olma Niyetinin Altında Yatan Faktörlerin Analizi. Zonguldak Karaelmas Üniversitesi Sosyal Bilimler Dergisi, 7(14): 145- 162.

Lafraire, Jeremie, Rioux, Camille, Giboreau, Agnes, and Picard, Delphine. 2016. Food Rejections in Children: Cognitive and Social/Environmental Factors Involved in Food Neophobia and Picky/Fussy Eating Behavior, Appetite, 96: 347-357.

Lam, Terry, and Hsu, Cathy H. C. 2004. Theory of Planned Behavior: Potential Travelers from China. Journal of Hospitality \& Tourism Research, 28(4): 463-482.

Lee, Tae-Hee, and Crompton, John. 1992. Measuring Novelty Seeking in Tourism, Annals of Tourism Research, 19(4): 732-751. 
Işın, A., Ünlüönen, K. / Journal of Yasar University, 2020, 15/59, 461-479

Levenstein, Harvey. 2013. “Gıda Korkusu: Beslenmeye Dair Endişelerin Tarihçesi (Çev. A. Öztek)”, İstanbul: İş Bankası Kültür Yayınları.

Lin, Jiayi, Julve, Jaume Guia, Xu, Honggang, and Cui, Qingming. 2018. Food Habits and Tourist Food Consumption: An Exploratory Study on Dining Behaviours of Chinese Outbound Tourists in Spain. Journal of Policy Research in Tourism, Leisure and Events. 1-18.

Logue, Alexandra W. 1991. “The Psychology of Eating and Drinking. 2nd Edition”, New York: Brunner-Routledge.

Long, Lucy M. 2004. “Culinary Tourism”. Lexington: The University Press of Kentucky.

Mak, Athena H. N., Lumbers, Margaret, Eves, Anita, and Chang, Richard C. Y. 2012. Factors Influencing Tourist Food Consumption. International Journal of Hospitality Management, 31 (3): 928-936.

Mak, Athena H. N., Lumbers, Margaret, Eves, Anita, and Chang, Richard C. Y. 2016. The Effects of Food-Related Personality Traits on Tourist Food Consumption Motivations. Asia Pacific Journal of Tourism Research, 22 (1): 1-20. DOI: 10.1080/10941665.2016.1175488

Makela, Johanna. 2000. “Cultural Definitions of the Meal”. Dimensions of the Meal: The Science, Culture, Business and Art of Eating edited by Meiselman, Herbert L. 7-18. Gaithersburg, Maryland: Aspen Publishers.

Marsh, Herbert W., Hau, Kit-Tai, Balla, John R., and Grayson, David. 1998. Is More Ever Too Much? The Number of Indicators per Factor in Confirmatory Factor Analysis. Multivariate Behavioral Research, 33 (2): 181-220.

Matzler, Kurt, Strobl, Andreas, Stokburger-Sauer, Nicola, Bobovnicky, Artur, and Bauer, Florian. 2016. Brand Personality and Culture: The Role of Cultural Differences on the Impact of Brand Personality Perceptions on Tourists' Visit Intentions. Tourism Management, 52: 507-520.

Meler, Marcel, and Cerovic, Zdenko. 2003. Food Marketing in the Function of Tourist Product Development. British Food Journal, 105(3): 175-192.

Mintz, Sidney W., and Du Bois, Christine M. 2002. The Anthropology of Food and Eating. Annual Review of Anthropology, 31(1): 99-119.

Mitchell, Richard,and Hall, C. Michael. 2003. “Consuming Tourists: Food Tourism Consumer Behaviour”, Food Tourism Around the World: Development, Management, and Markets edited by Hall, C. Michael, Sharples, Liz, Mitchell, Richard, Macionis, Niki, and Cambourne, Brock. 60-80. Butterworth Heineman, Oxford.

Mkono, Muchazondida, Markwell, Kevin, and Wilson, Erica. 2013. Applying Quan and Wang's Structural Model of the Tourist Experience: A Zimbabwean Netnography of Food Tourism. Tourism Management Perspective, 5 (0): 68-74.

Nevşehir İl Kültür ve Turizm Müdürlüğü (2018). Nevşehir İli Turizm İstatistikleri.

Okumus, Bendegül, and Cetin, Gürel. 2018. Marketing Istanbul as a Culinary Destination. Journal of Destination Marketing \& Management, 9: 340-346.

Overby, Jeffrey W., Gardial, Sarah Fisher, and Woodruff, Robert B. 2004. French Versus American Consumers' Attachment of Value to a Product in a Common Consumption Context: A Cross-National Comparison. Journal of the Academy of Marketing Science, 32(4): 432-460.

Özer, Leyla, Kement, Üzeyir, ve Gültekin, Beyza. 2015. Genişletilmiş Planlanmış Davranış Teorisi Kapsamında Yeşil Yıldızlı Otelleri Tekrar Ziyaret Etme Niyeti. Hacettepe Üniversitesi İktisadi ve İdari Bilimler Fakültesi Dergisi, 33 (4): 59-85.

Quintal, Vanessa Ann, Lee, Julie Anne, and Soutar, Geoffrey N. 2010. Risk, Uncertainty, and the Theory of Planned Behavior: A Tourism Example. Tourism Management, 31 (6): 797-805.

Pendergast, Donna. 2006. “Tourist Gut Reactions: Food Safety and Hygiene Issues”. Tourism in turbulent Times: Towards Safe Experiences for Visitors edited by Wilks, Jeff, Pendergast, Donna and Leggat, Peter. 143-154. Amsterdam: Elsevier.

Peter, J. Paul, and Olson, Jerry C. 2008. “Consumer Behavior and Marketing Strategy”, New York: McGraw-Hill.

Phetvaroon, Kullada. 2006. "Application of the Theory of Planned Behavior to Select a Destination After a Crisis: A Case Study of Phuket”, Thailand. Doctoral dissertation. Oklahoma State University, USA.

Pilgrim, Francis J. (1957). The Components of Food Acceptance and Their Measurement. American Journal of Clinical Nutrition, 5 (2): 171-175.

Pizam, Abraham, and Sussmann, Silvia. 1995. Does Nationality Affect Tourist Behavior? Annals of Tourism Research, 22(4): 901-917.

Pliner, Patricia, and Hobden, Karen. 1992. Development of a Scale to Measure the Trait of Food Neophobia in Humans. Appetite, 19(2): 105-120.

Pliner, Patricia, and Salvy, Sarah Jeanne. 2006. "Food neophobia in humans”. The Psychology of Food Choice edited by Shepherd, Richard, and Raats, Monique. 75-92. CABI, Oxfordshire.

Promsivapallop Pornpisanu, and Kannaovakun, Prathana. 2019. Destination Food Image Dimensions and Their Effects on Food Preference and Consumption. Journal of Destination Marketing \& Management, 11: 89-100.

Randall, Elizabeth, and Sanjur, Diva. 1981. Food Preferences: Their Conceptualization and Relationship to Consumption. Ecology of Food and Nutrition, 11(3): 151-161.

Raygor, Andrea. 2016. “The Theory of Planned Behavior: Understanding Consumer Intentions to Purchase Local Food in Iowa”. Master Thesis, Iowa State University.

Rozin, Paul, and Vollmecke, Teresa A. 1986. Food Likes and Dislikes. Annual Review of Nutrition, 6 (1): $433-456$. 
Rozin, Paul, Fischler, Claude, Imada, Sumio, Sarubin, Allison, and Wrzesniewski, Amy. 1999. Attitudes to Food and the Role of Food in Life in the USA, Japan, Flemish, Belgium and France: Possible Implication for the Diet-Health Debate. Appetite, 33 (2): 163-180.

Scarpato, Rosario. 2002. "Sustainable Gastronomy as a Tourist Product”. Tourism and Gastronomy edited by Hjalager, Anne-Mette, and Richards, Greg. 132-152. Routledge, London.

Seegebarth, Barbara, Behrens, Stefan Henrik, Klarmann, Christiane, Hennigs, Nadine, and Scribner Lisa Luebbehusen. 2016. Customer Value Perception of Organic Food: Cultural Differences and Cross-National Segments. British Food Journal, 118 (2): 396-411.

Semerci, Hüseyin ve Akbaba, Atilla. 2018. Bodrum'a Gelen Uluslararası Ziyaretçilerin Yerel Yemek Tüketimindeki Motivasyon Faktörlerinin Değerlendirilmesi. International Journal of Contemporary Tourism Research ,1: 4157.

Shin, Yeon Ho. 2014. "Local food Purchase Behavior of US Consumers: Application of an Extended Theory of Planned Behavior and Self-Congruity Theory”, Doctoral Dissertation, Oklahoma State University.

Shin, Yeon Ho, Im, Jinyong, Jung, Seung Eun, and Severta, Kimberly. 2018. The Theory of Planned Behavior and the Norm Activation Model Approach to Consumer Behavior Regarding Organic Menus. International Journal of Hospitality Management, 69: 21-29.

Sheldon, Pauline, and Fox, Morton. 1988. The Role of Foodservice in Vacation Choice and Experience: A Cross-Cultural Analysis. Journal of Travel Research, 27(3): 9-15.

Steenkamp, Jan-Benedict EM. 1997. "Dynamics in Consumer Behaviour with Respect to Agricultural and Food Products”, Agricultural Marketing and Consumer Behaviour in a Changing World edited by Wierenga, Berend, van Tilburg, Aad, Grunert, Klaus, Steenkamp, Jan-Benedict EM and Wedel, Michel. 143-188. Kluwer Academic Publishers.

Sparks, Paul, and Shepherd, Richard. 1992. Self-identity and the Theory of Planned Behavior: Assessing the Role of Identification with Green Consumerism. Social Psychology Quarterly. 55 (4): 388-399.

Telfer, David J., and Wall, Geoffrey. 2000. Strengthening Backward Economic Linkages: Local Food Purchasing by Three Indonesian Hotels. Tourism Geographies, 2(4): 421-447.

Tikkanen, Irma. 2007. Maslow's Hierarchy and Food Tourism in Finland: Five Cases. British Food Journal, 109 (9): $721-$ 734.

Torres, Rebecca. 2002. Toward a Better Understanding of Tourism and Agriculture Linkages in the Yucatan: Tourist Food Consumption and Preferences. Tourism Geographies. 4 (3): 282-306.

Tse, Peter, and Crotts, John C. 2005. Antecedents of Novelty Seeking: International Visitors’ Propensity to Experiment Across Hong Kong’s Culinary Traditions. Tourism Management, 26 (6): 965-968.

Uba, Laura. 1994. “Asian Americans: Personality Patterns, Identity, and Mental Health”, New York: Guiford Press.

UNWTO. 2017. “Annual Reports”, 2017 Edition.

Uşaklı, Ahmet. 2016. Turistik Tüketici Deneyimi: Beş Yıldızlı Resort Otellerde Bir Uygulama. Doktora Tezi, Gazi Üniversitesi.

Uşakl1, Ahmet, and Küçükergin, Kemal Gürkan. 2018. Using Partial Least Squares Structural Equation Modeling in Hospitality and Tourism: Do Researchers Follow Practical Guidelines? International Journal of Contemporary Hospitality Management, 30 (11): 3462-3512. https://doi.org/10.1108/IJCHM-11-2017-0753

van Rijswijk, Wendy, Frewer, Lynn J., Menozzi, Davide, and Faioli, Giusi. 2008. Consumer Perception of Traceability: A Cross-National Comparison of the Associated Benefits. Food Quality and Preference, 19 (5): $452-464$.

Verbeke Wim, and Vackier Isabelle. 2005. Individual Determinants of Fish Consumption: Application of the Theory of Planned Behaviour. Appetite, 44(1): 67-82.

Verma, Vivek Kumar, and Chandra, Bibhas. 2018. An Application of Theory of Planned Behavior to Predict Young Indian Consumers' Green Hotel Visit Intention. Journal of Cleaner Production, 172: 1152-1162.

Vermeir Isabelle, and Verbeke Wim. 2008. Sustainable Food Consumption Among Young Adults in Belgium: Theory of Planned Behaviour and the Role of Confidence and Values. Ecological Economics, 64(3): 542-553.

Vuksanović, Nikola Darko, Tešanović, Dragan, Kalenjuk, Bojana, and Portić, Milijanko. 2019. Gender, Age and Education Differences in Food Consumption within a Region: Case Studies of Belgrade and Novi Sad (Serbia), Acta Geographica Slovenica, 59 (2): pp.71-80.

Wang, Jie, and Ritchie, Brent W. 2012. Understanding Accommodation Managers'crisis Planning Intention: Anapplication of the Theory of Planned Behaviour. Tourism Management, 33(5): 1057-1067.

Weatherell, Charlotte, Tregear, Angela, and Allinson, Johanne. 2003. In Search of the Concerned Consumer: UK Public Perceptions of Food, Farming and Buying Local. Journal of Rural Studies, 19(2): 233-244.

Weaver, Pamela A., McCleary, Ken W., Han, Jiho and Blosser, Phillip E. 2009. Identifying Leisure Travel Market Segments Based on Preference for Novelty, Journal of Travel \& Tourism Marketing, 26(5/6): 568-584.

Wenzig, Julius, and Gruchmann, Tim. 2018. Consumer Preferences for Local Food: Testing an Extended Norm Taxonomy. Sustainability, 10 (5): 1313-1336.

Wright, Len Tiu, Nancarrow, Clive, and Kwok, Pamela M. H. 2001. Food Taste Preferences and Cultural Influences on Consumption. British Food Journal, 103(5): 348-357. 
Işın, A., Ünlüönen, K. / Journal of Yasar University, 2020, 15/59, 461-479

Zhang, Honglei, Li, Li, Yang, Yang, and Zhang, Jinhe. 2018. Why Do Domestic Tourists Choose to Consume Local Food? The Differential and Non-Monotonic Moderating Effects of Subjective Knowledge. Journal of Destination Marketing \& Management, 10: 68-77.

Zint, Michaela. (2002). Comparing Three Attitude-Behavior Theories for Predicting Science Teachers' Intentions. Journal of Research in Science Teaching, 39(9): 819-844. 